Ibrahem G. Wasti, Foo She Fui, Tan Qin Zhi, Cheh Wai Mun, Mohammad Hafiz Syukri Kassim, Mahadimenakbar Mohd Dawood, Noor Haliza Hasan, Vijay Kumar Subbiah, Faisal Ali Anwarali Khan, and Jaya Seelan Sathiya Seelan. Fungi from dead arthropods and bats of Gomantong Cave, northern Borneo, Sabah (Malaysia). Journal of Cave and Karst Studies, v. 82, no. 4, p. 261-275. DOI:10.4311/2019MB0146

\title{
FUNGI FROM DEAD ARTHROPODS AND BATS OF GOMANTONG CAVE, NORTHERN BORNEO, SABAH (MALAYSIA)
}

\author{
Ibrahem G. Wasti ${ }^{1}, 2$, Foo She Fui ${ }^{1}$, Tan Qin Zhi', Cheh Wai Mun¹, Mohammad Hafiz Syukri Kassim¹, \\ Mahadimenakbar Mohd Dawood', Noor Haliza Hasan', Vijay Kumar Subbiah³, Faisal Ali Anwarali \\ $\mathrm{Khan}^{4}$, and Jaya Seelan Sathiya Seelan ${ }^{1, \mathrm{C}}$
}

\section{Abstract}

Borneo is a biodiversity and ecotourism hotspot, yet one of its least-studied ecosystems is their limestone caves. Not many studies have been conducted on the role fungi play in tropical cave ecosystems, and no fungal surveys have been conducted in the caves of Sabah, Malaysia. Here, we assess the mycofloral diversity on bat and arthropod cadavers in one of the most popular ecotourism destinations of northern Borneo, Gomantong caves. Opportunistic sampling of cadavers within the Semud Hitam chamber of Gomantong cave yielded nine dead arthropods and four dead bats. Twenty-four culturable fungi were isolated, of which 14 morphological taxonomic units (MTU) were observed. Twelve of the 14 MTUs underwent molecular characterization of the ITS gene region to confirm identification. All fungi were Ascomycetes except for one Basidiomycete isolate. Aspergillus spp. had the highest occurrence (45.8\%), followed by Penicillium spp. (25.0\%), and Fusarium sp. (12.5\%). Ceratobasidium sp., Diaporthe sp., Pestalotiopsis sp., and Xylaria feejeensis were isolated once each. No more than one fungal taxon was isolated from each arthropod cadaver, and not all arthropods yielded culturable fungi. Bat cadavers yielded 14 out of 24 isolates (58.3\%), with the highest occurrence of the fungi sampled from their skin. Our results corroborate that bats and arthropods play a role in fungal dispersion and introduction in the cave because their exteriors are likely to harbor fungi they are exposed to in the environment. We also conclude that cadavers are important substrates for fungal growth and proliferation, perpetuating the role of fungi as important decomposers in caves. This study provides a baseline of information of the mycobiome of Bornean caves for future bioprospecting and potential biotechnological applications.

\section{INTRODUCTION}

The fungal diversity in caves and their influence on cave ecosystems have yet to be explored in Borneo. Many organisms cannot sustain themselves within the dark, cool, and nutrient-limited cave environment (Gunde-Cimerman et al., 1998). Despite this, fungi are one of the most dominant of all cave organisms with high rates of spore dissemination, colonization capability in various types of substrates, and tolerance to a wide range of pH values (Nováková, 2009; Bastian et al., 2010; Wang et al., 2010; Ogórek et al., 2013; Vanderwolf et al., 2013a). Over 1000 species of fungi stemming from over 500 genera have been found from caves throughout the world (Vanderwolf et al., 2013a). Most cave fungi are Ascomycetes, but Basidiomycetes and Zygomycetes are also found at lesser rates. Many of the fungi within caves are saprophytes that have been isolated from non-cave environments. While many cave-dwelling organisms are true troglobites, very few fungi are specialized in the cave ecosystem. It is the most likely scenario that cave fungi originated from environments external to caves (Zhang et al., 2017).

Fungi are known to interact with a wide array of organisms and play an important role in the greater ecosystems they are a part of, whether as symbionts, parasites, saprophytes, or a food source (Bastian et al., 2010; Arouja and Hughes, 2016). In wild animals, fungi found on ears, lungs, intestines, bladder, kidney, animal dung, brain, and skin may lead to fungal infections (Ainsworth and Austwick, 1955; Seelan et al., 2008, 2009). A few fungal species cause diseases in mammals because their high body temperatures promote fungal growth (Bergman and Casadevall, 2010; Garcia-Solache and Casadevall, 2010). For example, white-nose syndrome (WNS) is a disease that affects hibernating bats. It is caused by a visible white fungus, Pseudogymnoascus destructans, that grows on bats' muzzles and wings and has killed millions of bats in North America (Blehert et al., 2009; Lorch et al., 2011; Warnecke et al., 2012). Many non-pathogenic keratinophillic fungi can survive on animal fur, possibly due to less competition from soil fungi with higher saprophytic ability (Rees, 1967). Keratinophillic fungi have been isolated from animals such as cats, dogs, cows, rabbits, horses, rats, and donkeys (Aho, 1983; Bagy, 1986; Ali-Shtayeh et al., 1988). The most common fungi isolated from animals include Aspergillus spp., Penicillium spp., Cladosporium spp. and Mucor spp. (Aho, 1983; Ali-Shtayeh et al., 1988). Fungal dermatophytes have also been isolated from domestic animals, namely Trichophyton spp. and

\footnotetext{
${ }^{1}$ Institute for Tropical Biology and Conservation, Universiti Malaysia Sabah, 88400 Jalan UMS, Kota Kinabalu, Sabah, Malaysia

${ }^{2}$ Faculty of Natural Science and Sustainability, University College Sabah Foundation, Jalan Sanzac, Sembulan, 88100 Kota Kinabalu, Sabah,

Malaysia

${ }^{3}$ Biotechnology Research Institute, Universiti Malaysia Sabah, 88400 Jalan UMS, Kota Kinabalu, Sabah, Malaysia

${ }^{4}$ Faculty of Resource Science and Technology, Universiti Malaysia Sarawak, 94300 Kota Samarahan, Sarawak, Malaysia

cCorresponding author: seelan80@ums.edu.my
} 
Microsporum spp., which shows that they are important in the transmission of disease-causing fungi (Ali-Shtayeh et al., 1988). Some keratinophilic fungal species isolated from domestic animals are pathogenic to humans and animals, namely A. fumigatus, Stachybotrys chartarum, Scopulariopsis brevicaulis, and Cephalosporium acremonium (Bagy, 1986). Isolation of fungi from animals, especially those from biodiversity-rich ecosystems like the tropics, may lead to the important discovery of novel bioactive compounds (Higginbotham et al., 2014). They showed that fungi isolated from sloth hair have anti-malarial, anti-bacterial, and anti-cancer bioactivity.

Although previous studies on the fungal biomes of bats in Borneo have been conducted, they were not done on bats that were captured in or near a cave environment (Seelan et al., 2008, 2009). Around the world, a plethora of studies on cave fungi from a variety of different substrates have been conducted, including bats, bat guano, invertebrates, soil, rocks, walls, water, and air (Vanderwolf et al., 2013a). In another study, thirty bats from four caves and one mine in the United States yielded 182 fungal isolates (Johnson et al., 2013). These fungi were mainly from the division Ascomycota, while Basidiomycota only made up $14 \%$ of the isolates. The most common genera isolated from the bat wings were Cladosporium, Fusarium, Mortierella, and Penicillium. A study on cave walls, ceilings, and sediment from six caves led to the discovery of 675 fungal isolates composed mainly of Ascomycota, suggesting that common cosmopolitan ascomycetes will likely dominate studies that utilize culture-dependent methods (Zhang et al., 2014). While different hosts and substrates in caves result in varying assemblages of fungi, it has been suggested that the specific environmental characteristics of the cave itself plays a significant role on the type of fungi isolated (Johnson et al., 2013; Vanderwolf et al., 2016a).

Arthropod-associated fungi and entomopathogenic fungi have been isolated from caves from many regions of the world (Gunde-Cimerman et al., 1998; Santamaria and Faille, 2007; Jurado et al., 2008; Yoder et al., 2009; Polovinko et al., 2010; Bastian et al., 2010; Porca et al., 2011; Vanderwolf et al., 2016a). Cave invertebrates can thrive in the nutrient-limited cave environment because they are able to utilize a broad range of food sources for sustenance (Smrž et al., 2015). Fungal conidia can act as a food source for cave insects, as demonstrated with Folsomia candida (Smrž et al., 2015). Cave isopods were shown to prefer saprophytic fungi growing on bat guano as one of their food sources because it is a source of polyunsaturated fatty acids, an essential nutrient. A world review of cave fungi showed that 201 species of fungi from 89 genera had been isolated from arthropods (Vanderwolf et al., 2013a). Most of these were Ascomycetes and Zygomycetes. Many entomopathogenic fungi in caves are specialized to infect specific hosts. For example, Rhachomyces spp. are infectious to carabid beetles that are highly specialized to the cave environment (Santamaria and Faille, 2007). Cave entomopathogenic fungi may also be generalists by nature. For example, the known generalist insect pathogen, Beauveria bassiana, was isolated from multiple dead insects in the caves of West Siberia and made up $68 \%$ of all isolates (Polovinko et al. 2010). Furthermore, arthropods may carry fungal spores that are pathogenic to other cave fauna (Vanderwolf et al., 2016b). Despite the importance of cave fungal studies that have been conducted on all the major continents of the world, none have been conducted in Malaysian Borneo (Vanderwolf et al., 2013a).

The Gomantong cave system $\left(5^{\circ} 31^{\prime} 30^{\prime \prime} \mathrm{N} 118^{\circ} 04^{\prime} 15^{\prime \prime} \mathrm{E}\right)$ is located in the 3,297 hectare Gomantong Forest Reserve, Kinabatangan, Sabah (North Borneo), and it is part of the largest limestone outcrop in the area, Gomantong Hill (Lundberg and McFarlane, 2012). Kinabatangan is known for its rich biodiversity, where at least 51 mammal species, including 10 primate species, have been recorded in the area (Boonratana and Sharma, 1997). The area surrounding the forest reserves are almost exclusively utilized for the monocrop production of palm oil. The cave itself is famous for its swiftlet nest farming and birds nest harvesting (Ismail, 1999; Hobbs, 2004; Lundberg and McFarlane, 2012). Since 2012 , Gomantong caves get around 13,000 to 15,000 thousand visitors annually, mostly composed of foreigners, according to the Sabah Wildlife Department. At least 13 species of bats have been recorded from this cave, including some of the common Hipposideros spp., Rhinolopus spp., and Myotis gomantongensis (Abdullah et al., 2007). So far, there has not been any entomological or mycological survey studies conducted in Gomantong cave.

With the development of species barcodes in ecological studies, there are now large amounts of phylogenetic data on species isolated in caves (Woese et al., 1990; Barton et al., 2004; Lahaye et al., 2008). However, no such studies on cave mycota have been published on the caves of Sabah. With the help of DNA barcoding, establishing baseline ecological data for fungal species in areas where these types of studies are scant increases the possibility of discovering novel fungi.

\section{MATERIALS AND METHODS}

\section{Site Description}

Semud Hitam, Gomantong cave was visited twice, on October 6, 2017 and January 23, 2018 (Fig. 1). The cave is composed of two main sections, Semud Hitam (Black Cave) and Semud Putih (White Cave). Birds nest harvesting apparatus are visible throughout the cave, and the harvesting itself is done by employees of the municipality (Lundberg 


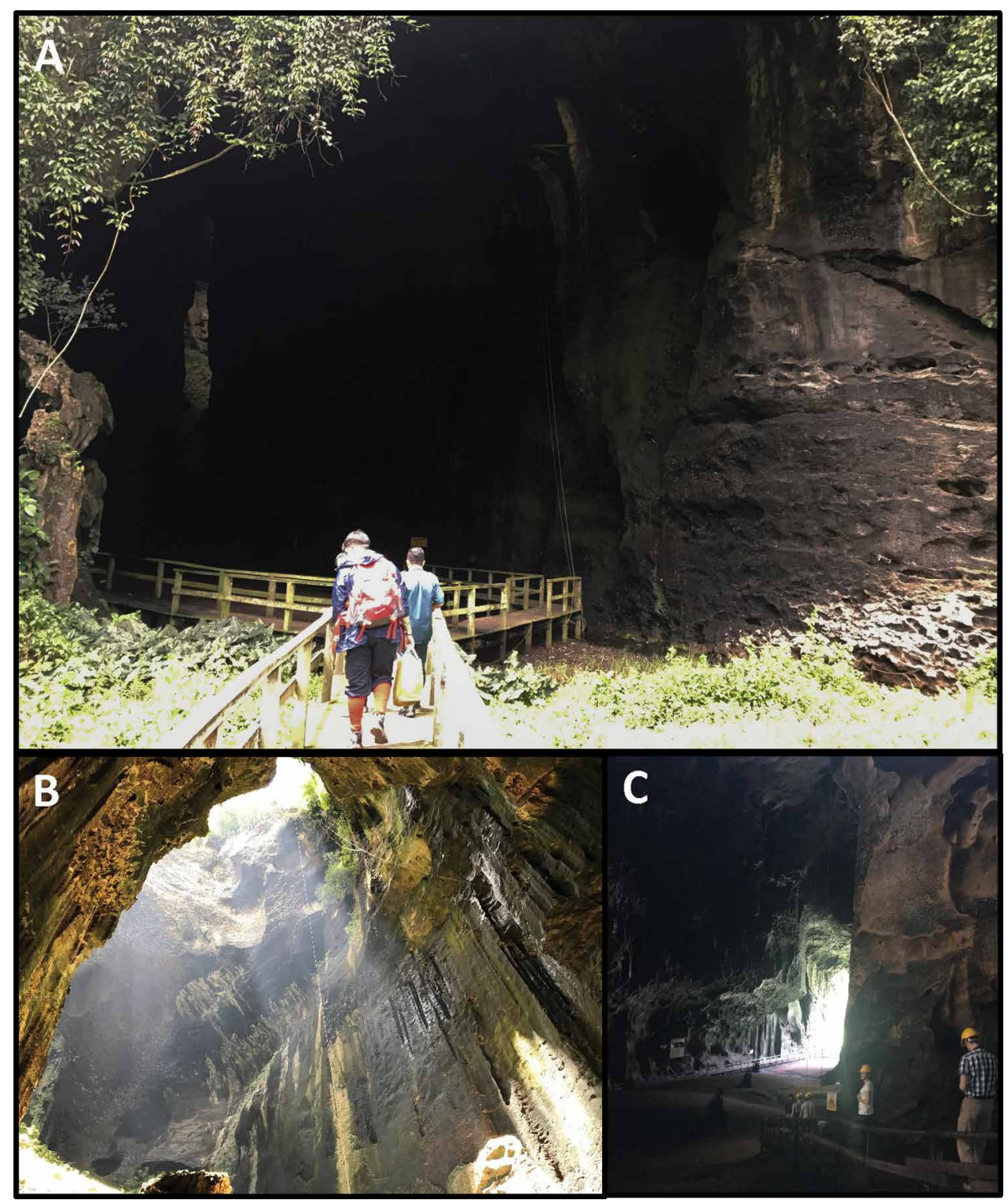

Figure 1. A. Cave entrance of Semud Hitam, Gomantong Cave. B. Ceiling opening at the back end of Semud Hitam. C. Foreign tourists on boardwalk passage in the cave. Note that the boardwalk was built for ease of access for people as piles of bat guano and running water streams cover the cave floor. light zone of each sample were also recorded during sampling (Table 2). The arthropod cadavers were stored in a cooler filled with ice until transportation back to the laboratory where samples were stored at $4{ }^{\circ} \mathrm{C}$. Bat cadavers were in the early stages of decomposition and had no obvious signs of fungal growth. They were identified on site and subsequently swabbed using sterile cotton swabs on five different body parts (i.e. anus, ear, skin, mouth, and hair). The swabs were inoculated into sterile centrifuge tubes containing $900 \mu \mathrm{L}$ PBS buffer until further processing.

\section{Fungal Isolation}

In the laboratory, arthropod cadavers were identified to at least the genus level by using dichotomous keys (Imes, 1992; Chinery, 2005). Any hyphae visibly growing from the cadaver were inoculated onto Potato Dextrose Agar (PDA) incorporated with the antibiotic streptomycin sulfate $(40 \mu \mathrm{g} / \mathrm{mL})$. Isolations were performed in triplicate using the threepoint method until pure isolates were produced. Bat cadaver swab samples were serially diluted 10 -fold up to $10^{-4}$. Of the $10^{-2}$ to $10^{-4}$ dilutions, $0.1 \mathrm{~mL}$ aliquots were spread on the PDA plates. Dilutions were performed in triplicate using sterile distilled water. All inoculated plates were incubated for 3-7 days at room temperature $\left(25^{\circ} \mathrm{C}\right)$ and in the dark. Isolates were grouped into morphological taxonomic units (MTU) based on the colony morphology and micro-morphological characteristics, i.e. colony color, texture, growth patterns, hyphae, conidia size and shape, and conidiophores. 


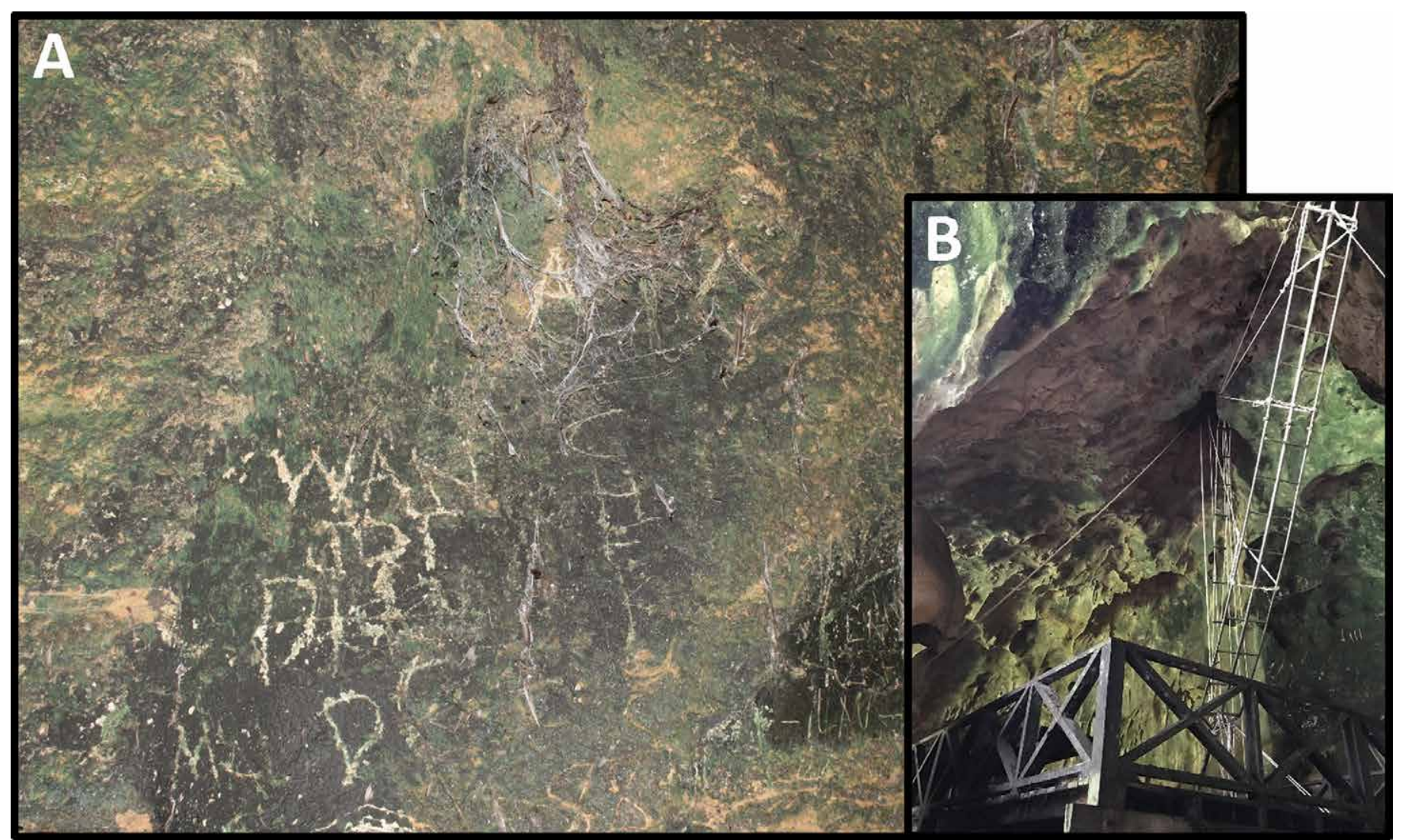

Figure 2. A. Vandalism on the cave wall by tourists. B. One of the swiftlet nest harvesting apparatus. Care takers of the swiftlet nest farms reside in shacks immediately outside the cave.

Table 1. Temperature and relative humidity in Gomantong cave. The approximate distance from cave entrance and light zone were also recorded.

\begin{tabular}{|c|c|c|c|c|c|c|c|c|c|}
\hline \multirow[b]{2}{*}{ Date } & \multicolumn{3}{|c|}{ Light Zone } & \multicolumn{3}{|c|}{ Twilight Zone } & \multicolumn{3}{|c|}{ Dark Zone } \\
\hline & Temp, ${ }^{\circ} \mathrm{C}$ & $\mathrm{RH}, \%$ & Dist., m & Temp, ${ }^{\circ} \mathrm{C}$ & $\mathrm{RH}, \%$ & Dist., m & Temp, ${ }^{\circ} \mathrm{C}$ & $\mathrm{RH}, \%$ & Dist., $\mathrm{m}$ \\
\hline Oct 6, 2017 & 29 & 93 & 5 & 26 & 100 & 35 & 26 & 100 & 70 \\
\hline Jan 23, 2018 & 30 & 92 & 5 & 29 & 92 & 35 & 27 & 100 & 70 \\
\hline
\end{tabular}

Identifications were carried out by comparing the morphological characteristics of the fungi to universal identification keys described by Raper and Fennell (1965), Klich (2002), and Domsch et al. (2007).

\section{PCR Amplification and Sequencing}

Molecular identification was performed on all arthropod cadaver fungi isolates and on six bat cadaver fungi isolates. The E.Z.N.A DNA Fungal Kit (Omega Bio-Tek, USA) was used to extract DNA from pure cultures of isolates according to the manufacturer's instruction. The $5.8 \mathrm{~S}$ sequences were amplified with primers ITS1 (5'-TCC GTA GGT GAA CCT GCG G-3') and ITS4 (5'-TCC TCC GCT TAT TGA TAT TGA TAT GC-3') (White et al.; 1990) (Vilgalys Mycology Lab). PCR amplification was carried out in a total volume of $50 \mu \mathrm{L}$ with the following reagents from Promega (USA): $2 \mu \mathrm{L}$ of each primer (10 pmol/ $\mu \mathrm{L}), 0.25 \mu \mathrm{L}$ Taq DNA polymerase (5 units/ $\mu \mathrm{L}), 10 \mu \mathrm{L}$ PCR Buffer (5X), $4 \mu \mathrm{L} \mathrm{MgCl}{ }_{2}(25 \mathrm{mM}), 1 \mu \mathrm{L}$ dNTPmix (10mM), $2 \mu \mathrm{L}$ DNA template $(\sim 25 \mathrm{ng} / \mathrm{mL})$. PCR cycles were performed in a Bio Rad T100 Thermal Cycler. For amplification, the conditions were $95^{\circ} \mathrm{C}$ for $3 \mathrm{~min}$ of the initial denaturation, followed by 35 cycles of $94^{\circ} \mathrm{C}$ for $30 \mathrm{~s}$ of denaturation, $53^{\circ} \mathrm{C}$ for $30 \mathrm{~s}$ of annealing, and $72^{\circ} \mathrm{C}$ for 1 min of extension. A final extension of $72{ }^{\circ} \mathrm{C}$ for 10 min was added to complete the process. The PCR products were then electrophoresed in a $1 \%$ agarose gel for 30 mins and subsequently stained with gel red for visualization. Next, the PCR products were purified using Column-Pure PCR Clean-Up Kit (Applied Biological Materials, Inc., Richmond, BC) according to the protocol of the manufacturer. DNA sequencing was performed using the BigDye Terminator v3.1 on a ABI3500 sequencer (Applied Biosystems). Sequencing service was provided by MyTACG (Taiwan). The ITS forward and reverse primers were used in the cycle sequencing. The resulting reads were aligned to obtain the full-length amplicon sequence (BioEdit version 7.0.5.3) and submitted to GenBank. Once the sequencing was completed, the ITS barcode sequences generated from all isolates were queried against NCBI nu- 

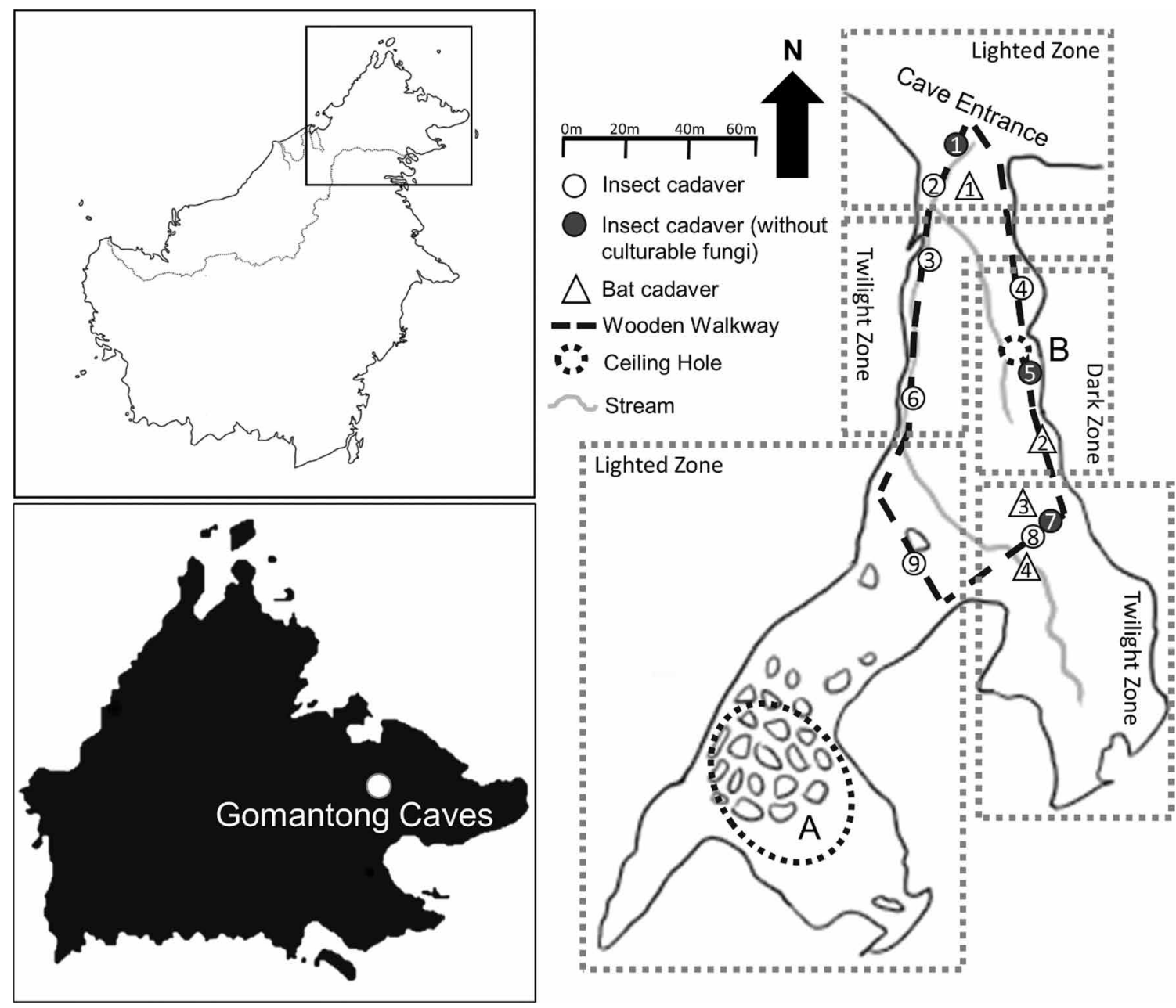

Figure 3. Layout of Semud Hitam, Gomantong Cave, Sukau, Sabah Malaysia. The cave entrance is located in the north end of the cave. The cave is accessible via a wooden walkway that was built for ease of access for tourists and swiftlet nest farmers. The tall mouth of the cave entrance and the presence of two large ceiling apertures (A and B) make the cave relatively well-lit during the afternoon hours. There are areas that do not receive direct sunlight and other areas that are completely dark hidden between walls, nooks, and crevices. All 14 cadavers were collected and their relative distances from the cave entrance measured and labelled by light zone. cleotide sequence using basic local alignment search tool (BLASTn) to ascertain their closest relationships (Zhang et al., 2000).

\section{RESULTS}

Fungi are prevalent in the cave environment, and cave fauna, wind, water, and humans all play important roles in spore dispersion and translocation in and out of the cave. In the current study, a total of 24 axenic fungal isolates were obtained from six out of nine arthropod cadavers and all four bat cadavers sampled (Table 2). Ten pure cultures were isolated from arthropod cadavers and 14 from bat cadavers (Table 3). Isolated fungi were separated

Table 2. Distance of arthropod and bat cadaver samples from the entrance and number of fungal isolates obtained.

\begin{tabular}{|c|c|c|c|c|}
\hline Light Zone & Sample ID & Sample species & $\begin{array}{l}\text { Distance from } \\
\text { Entrance, } m\end{array}$ & $\begin{array}{l}\text { No. of Fungal } \\
\text { Isolates }\end{array}$ \\
\hline \multirow[t]{4}{*}{ Lighted } & $\mathrm{A} 01$ & Periplaneta americana & 8 & 0 \\
\hline & A02 & Thereuopoda sp. & 20 & 2 \\
\hline & A09 & Periplaneta americana & 108 & 1 \\
\hline & B01 & Cynopterus brachyotis & 19 & 8 \\
\hline \multirow[t]{6}{*}{ Twilight } & A03 & Periplaneta americana & 28 & 2 \\
\hline & A06 & Periplaneta americana & 63 & 1 \\
\hline & $\mathrm{A} 07$ & Periplaneta americana & 91 & 0 \\
\hline & A08 & Trigonilus corallinus & 93 & 1 \\
\hline & B03 & Balionycteris maculata & 85 & 2 \\
\hline & B04 & Chaerephon plicatus & 94 & 1 \\
\hline \multirow[t]{3}{*}{ Dark } & A04 & Trigonilus corallinus & 33 & 3 \\
\hline & A05 & Thereuopoda sp. & 45 & 0 \\
\hline & B02 & Hipposideros diadema & 76 & 3 \\
\hline
\end{tabular}


Wasti, Fui, Zhi, Mun, Kassim, Dawood, Hassan, Subbiah, Khan, and Seelan

Table 3. Fungi isolated per insect and bat cadaver species. Body parts sources are listed for bat cadaver hosts.

\begin{tabular}{|c|c|c|c|}
\hline Host Species & Fungal Species & Source & No. of isolates \\
\hline \multicolumn{4}{|l|}{ Arthropod } \\
\hline \multirow[t]{4}{*}{ Periplaneta americana } & Aspergillus flavus & Wings & 1 \\
\hline & Aspergillus luteovirescens & Abdomen & 1 \\
\hline & Ceratobasidium sp. & Thorax & 1 \\
\hline & Fusarium solani & Thorax & 1 \\
\hline \multirow[t]{2}{*}{ Thereuopoda sp. } & Fusarium solani & Abdomen & 1 \\
\hline & Penicillium sclerotiorum & Abdomen & 1 \\
\hline \multirow[t]{4}{*}{ Trigonilus corallinus } & Aspergillus sclerotiorum & Body & 1 \\
\hline & Diaporthe sp. & Body & 1 \\
\hline & Fusarium solani & Body & 1 \\
\hline & Penicillium shearii & Head & 1 \\
\hline \multicolumn{4}{|l|}{ Bat } \\
\hline Balionycteris maculata & Aspergillus restrictus & Skin, Hair & 2 \\
\hline \multirow[t]{5}{*}{ Cynopterus brachyotis } & Aspergillus flavus & Skin & 1 \\
\hline & Aspergillus ochraceus & Ear & 1 \\
\hline & Aspergillus restrictus & Anal, Skin, Ear & 3 \\
\hline & Penicillium citrinum & Skin, Oral & 2 \\
\hline & Pestalotiopsis sp. & Oral & 1 \\
\hline \multirow[t]{2}{*}{ Hipposideros diadema } & Aspergillus restrictus & Hair & 1 \\
\hline & Penicillium paxilli & Skin, Hair & 2 \\
\hline Chaerephon plicatus & Xylaria feejeensis & Oral & 1 \\
\hline
\end{tabular}

Table 4. Molecular characterization based on ITS barcode similarities to the NCBI database.

\begin{tabular}{|c|c|c|c|c|}
\hline Isolate & NCBI Identification & E value & Identification, \% & Host Species \\
\hline GMT01 & Fusarium solani & 0.0 & 97.4 & Thereupoda sp. (A02) \\
\hline GMT02 & Penicillum sclerotiorum & 0.0 & 98.2 & Thereupoda sp. (A02) \\
\hline GMT03 & Fusarium solani & 0.0 & 99.8 & Periplaneta americana (A03) \\
\hline GMT04 & Ceratobasidium sp. & 0.0 & 96.2 & Periplaneta americana (A03) \\
\hline GMT05 & Diaporthe sp. & 0.0 & 98.8 & Trigonilus corallinus (A04) \\
\hline GMT06 & Aspergillus sclerotiorum & 0.0 & 100 & Trigonilus corallinus (A04) \\
\hline GMT07 & Fusarium solani & 0.0 & 99.0 & Trigonilus corallinus (A04) \\
\hline GMT08 & Aspergillus luteovirescens & 0.0 & 99.8 & Periplaneta americana (A06) \\
\hline GMT09 & Penicillium shearii & 0.0 & 99.7 & Trigonilus corallinus (A08) \\
\hline GMT10 & Aspergillus flavus & 0.0 & 100 & Periplaneta americana (A09) \\
\hline GMC05 & Penicillium paxilli & 0.0 & 100 & Hipposideros diadema (B02) \\
\hline GMC06 & Penicillium paxilli & 0.0 & 100 & Hipposideros diadema (B02) \\
\hline GMC09 & Xylaria feejeensis & 0.0 & 99.7 & Chaerephon plicatus (B04) \\
\hline GMC10 & Penicillium citrinum & 0.0 & 99.5 & Cynopterus brachyotis (B01) \\
\hline GMC14 & Aspergillus flavus & 0.0 & 100 & Cynopterus brachyotis (B01) \\
\hline GMC15 & Penicillium citrinum & 0.0 & 100 & Cynopterus brachyotis (B01) \\
\hline
\end{tabular}




\section{Fungal Species Occurence}

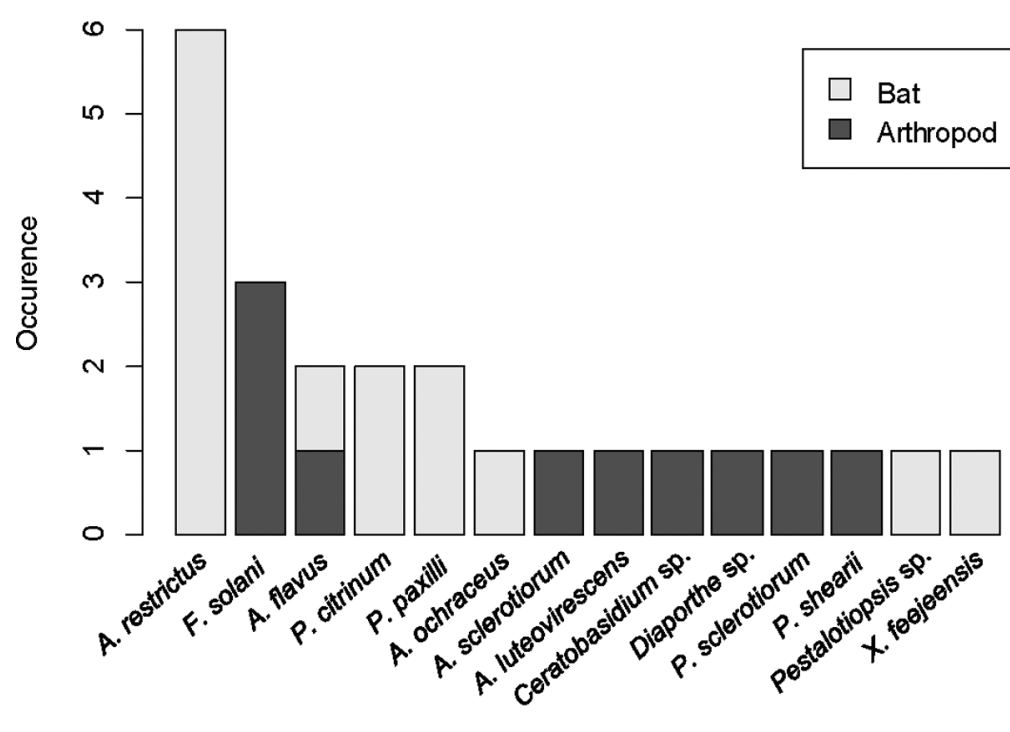

Species

Figure 4. Fungal species occurrence from bat and arthropod cadavers in Gomantong Cave. A. restrictus was the mode $(n=6)$, followed by $F$. solani $(n=3)$. into 14 MTUs based on their macro- and micromorphology. Sixteen out of the 24 pure isolates underwent molecular characterization. Molecular analysis was prioritized for isolates that could not be identified solely on morphology and to corroborate identification of cryptic taxa at the species level. The ITS barcode PCR amplicons were about $600 \mathrm{bp}$ in size for all of the 16 isolates. After DNA sequencing, the BLASTn data from the 16 isolates resulted in 11 operational taxonomic units (OTU) (Table 4). The results indicated that all OTUs belonged to the division Ascomycota except for Ceratobasidium sp., from the division Basidiomycota. The majority of the isolated strains belonged to the order Eurotiales and the family Aspergillaceae. For the Ceratobasidium sp. and Diaporthe sp. isolates reported in this study, ITS gene sequences were not enough to differentiate the isolates up to the species level. The fungal genera isolated were Aspergillus (45.8\%), Penicillium (25.0\%), Fusarium (12.5\%), Ceratobasidium (4.2\%), Diaporthe (4.2\%), Pestalotiopsis (4.2\%), and Xylaria (4.2\%). Asper-

gillus restrictus was isolated a total of six times, accounting for $25 \%$ of all isolates (Fig, 4).

We observed that different species of fungi were present on different species of arthropods (Figs. 5 and 6). Four species of fungi were isolated from Periplaneta americana (Cockroach) and Trigonilus corallinus (Asian/Rusty millipede) cadavers. Thereuopoda sp. (Gantcave/Cave centipede) recorded only two species of fungal isolates.

Four different species of bat cadavers were collected during sampling for this study. Cynopterus brachyotis (Lesser short-nosed fruit bat) yielded five species of fungi, which was the most for any one sample in this study. Two species of fungi were isolated from Hipposideros diadema (Diadem leafnosed bat). Only one species of fungi was isolated from each Balionycteris maculata (Spotted-winged fruit bat) and Chaerephon plicatus (Wrinkle-lipped free-tailed bat) cadaver. The bats' skin had the highest di-
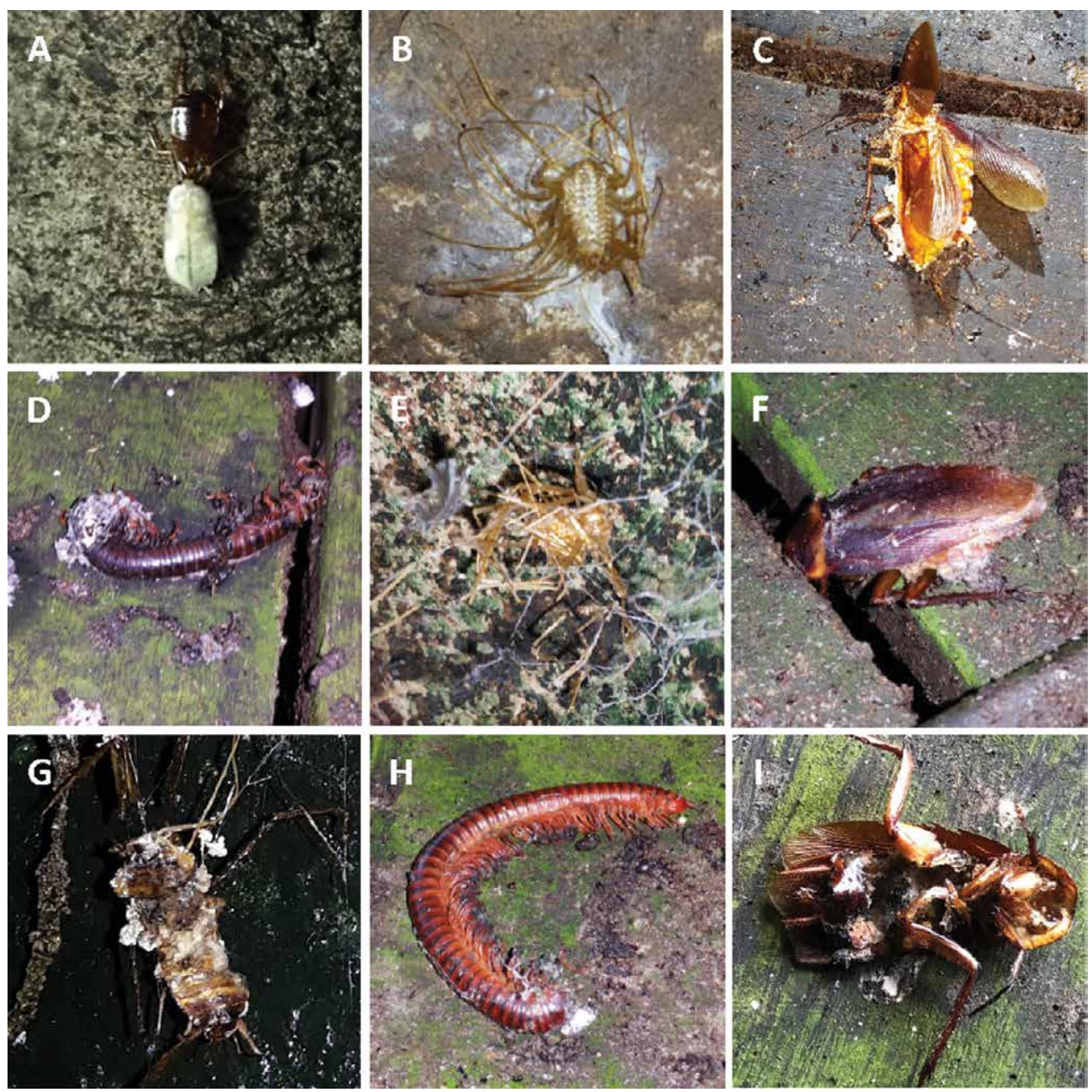

Figure 5. Dead arthropod samples in order of distance from entrance. A. A01, P. americana. B. A02, Thereuopoda sp.. C. A03, P. americana. D. A04, T. corallinus. E. A05, Thereuopoda sp.. F. A06, P. americana. G. A07, P. americana. H. A08, T. corallinus. I. A09, P. americana. 


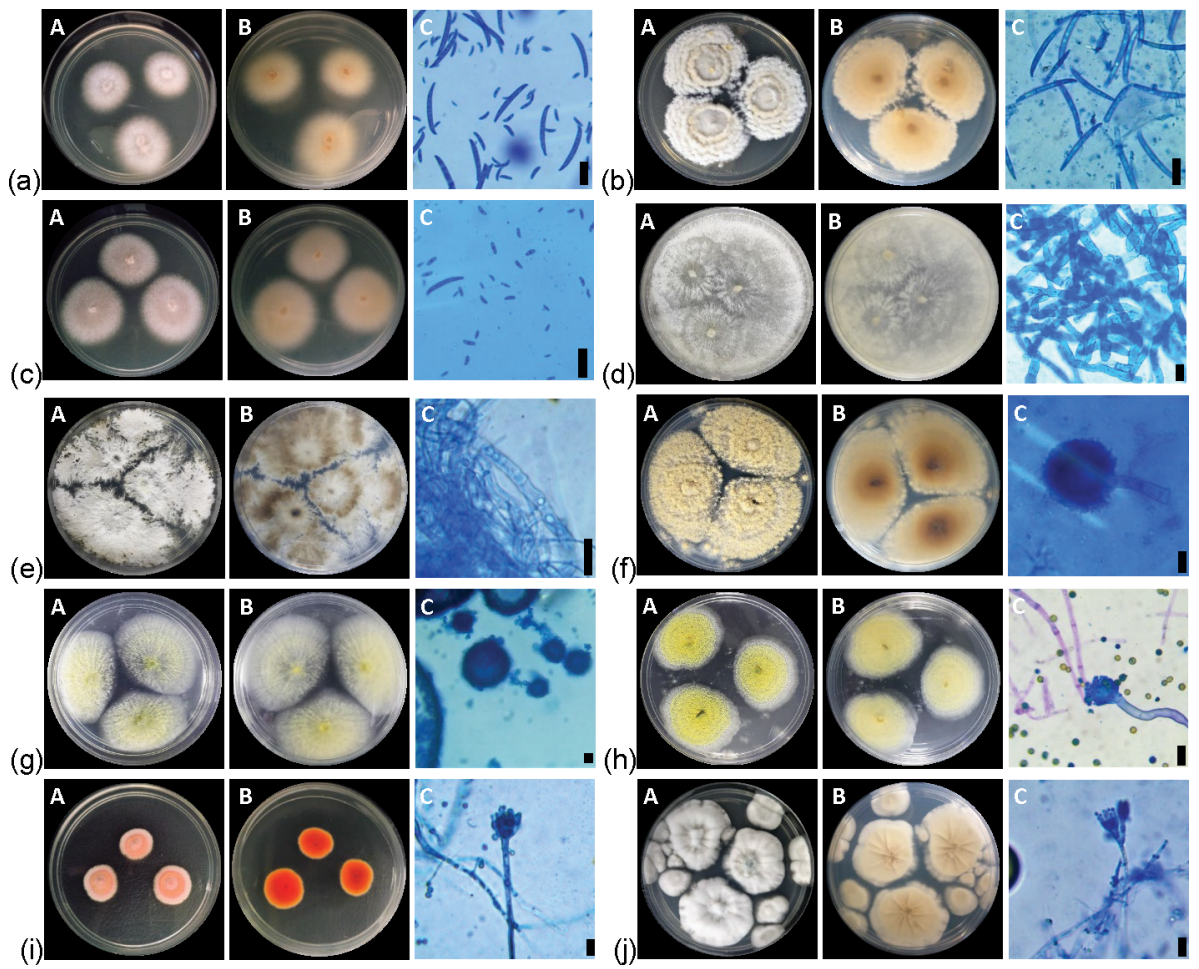

Figure 6. (a) Fusarium solani GMT01; (b) GMT03; (c) GMT07; (d) Ceratobasidium sp. GMT04; (e) Diaporthe sp. GMT05; (f) Aspergillus sclerotiorum GMT06; (g) Aspergillus terricola GMT08; (h) Aspergillus flavus GMT10; (i) Penicillium sclerotiorum GMT02; (j) Penicillium shearii GMT09. A. Colony surface on PDA. B. Colony reverse on PDA. C. Micromorphological characteristics (i.e. conidia, conidiophores, hyphae). Scale $=10 \mu \mathrm{m}$.

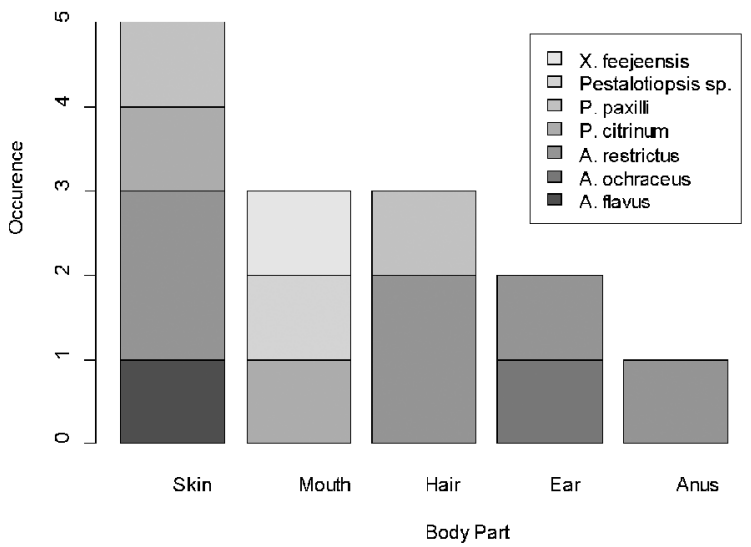

Figure 7. Number of fungal isolates per body part. The skin of bats had the highest fungal isolates $(n=5,4$ species), and anus had the lowest ( $n=1,1$ species). versity and occurrence for any of the body parts with four species of fungi from five isolates (Fig. 7). The different fungal isolates from all bat cadavers are shown (Fig. 8).

\section{DISCUSSION}

Ours is the first study that describes the occurrence of fungi in a cave from Sabah, Malaysia. Fourteen fungal isolates were found on bat cadavers and ten fungal isolates from arthropod cadavers in this study. Both the bat and arthropod cadavers had similar fungal diversity, each yielding eight different species of fungi. Twenty-three of the 24 fungal isolates found in the study were ascomycetes, the remaining one being Ceratobasidium sp., a basidiomycete. The most frequently isolated fungal genera in this study were Aspergillus, Penicillium, and Fusarium, which are ubiquitous in non-cave environments (Domsch et al., 2007). Findings from this study are congruent with previous reports where the Ascomycota, especially fungi from genera Aspergillus, Fusarium, and Penicillium, are the dominant division of fungi isolated from cave environment (Nováková, 2009; Voyron et al., 2011, Vanderwolf et al., 2013a). A study conducted previously on cadavers and skeletons of various fauna from cave and mine environments found that 12 out of 39 fungal isolates were identified as Mucoromycota (Nováková et al., 2018). Mucor is considered as one of the dominant genera of fungi isolated from cadavers throughout the various stages of decomposition along with Aspergillus, Penicillium, and Candida (Sidrim et al., 2009). The lack of Mucoromycota in this study may be explained by difference in media type used in our study compared to theirs. Using exclusively PDA and MEA during incubation and isolation in this study likely gave preference for rapidly growing ubiquitous fungi, especially Aspergillus and Penicillium.

Most studies on cave fungi utilize culture-dependent methods of isolation before proceeding to morphological or molecular characterization (Vanderwolf et al., 2013a; Man et al., 2015; Zhang et al.,

2017; Nováková et al., 2018; Visagie et al., 2019). Because of limited finances, manpower, and time, this initial study exclusively utilized culture-based methods of isolation. Culture-independent community-based studies on cave fungi are scant, but they have been conducted in recent years (Zhang et al., 2014; Zhang and Cai, 2019). Culture-based methods tend to produce results that over-represent rapidly growing cosmopolitan fungi. Whether fastidious fungi will grow and be observed in culture is heavily influenced by temperature, length of incubation, type of medium used, and aerobic conditions (Bills, 1995; Collado et al., 2007; Unterseher and Schnittler, 2009; Tristan et al., 2012). Culture-dependent methods are known to only reveal around $0.6-8.0 \%$ of total the total fungal species in a sample (Hibbett et al., 2009; Hawksworth and Lucking, 2017) so culture-dependent methods are greatly limiting and hinder our understanding of the overall role fungi play in the ecosystems they inhabit. Community based culture-independent methods can generate millions of raw sequences at a time, yielding in the hundreds to thousands of fungal OTUs per sample (Winter et al., 2017; Zhang and Cai, 2019). On the other hand, Zhang and Cai (2019) reported that culture-dependent and culture-independent methods tend to show similar fungal diversity, but culture-independent methods are more likely to find uncommon fungi in their re- 
(a)
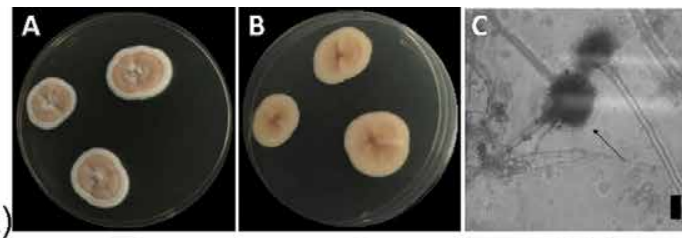

(c)
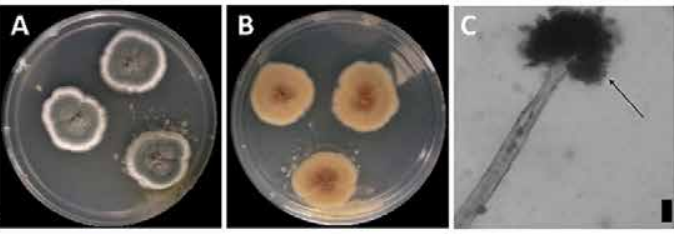

(b)
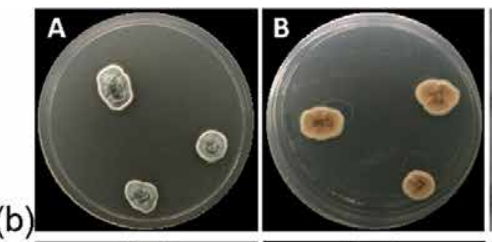

(d)
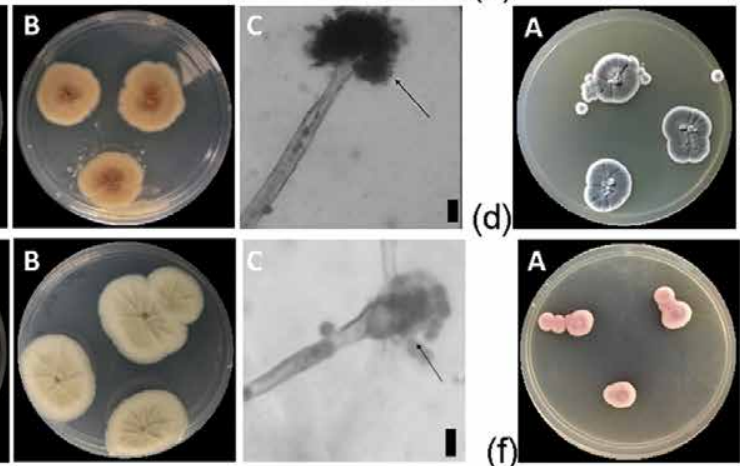

(e)

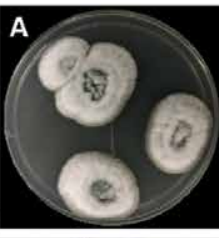

(g)
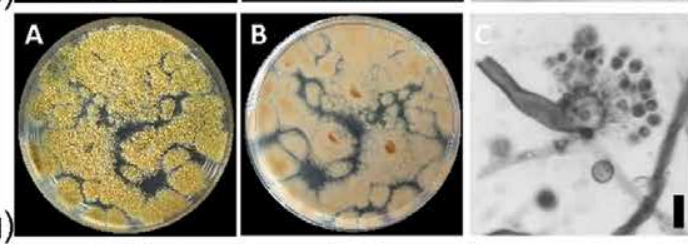

(f)
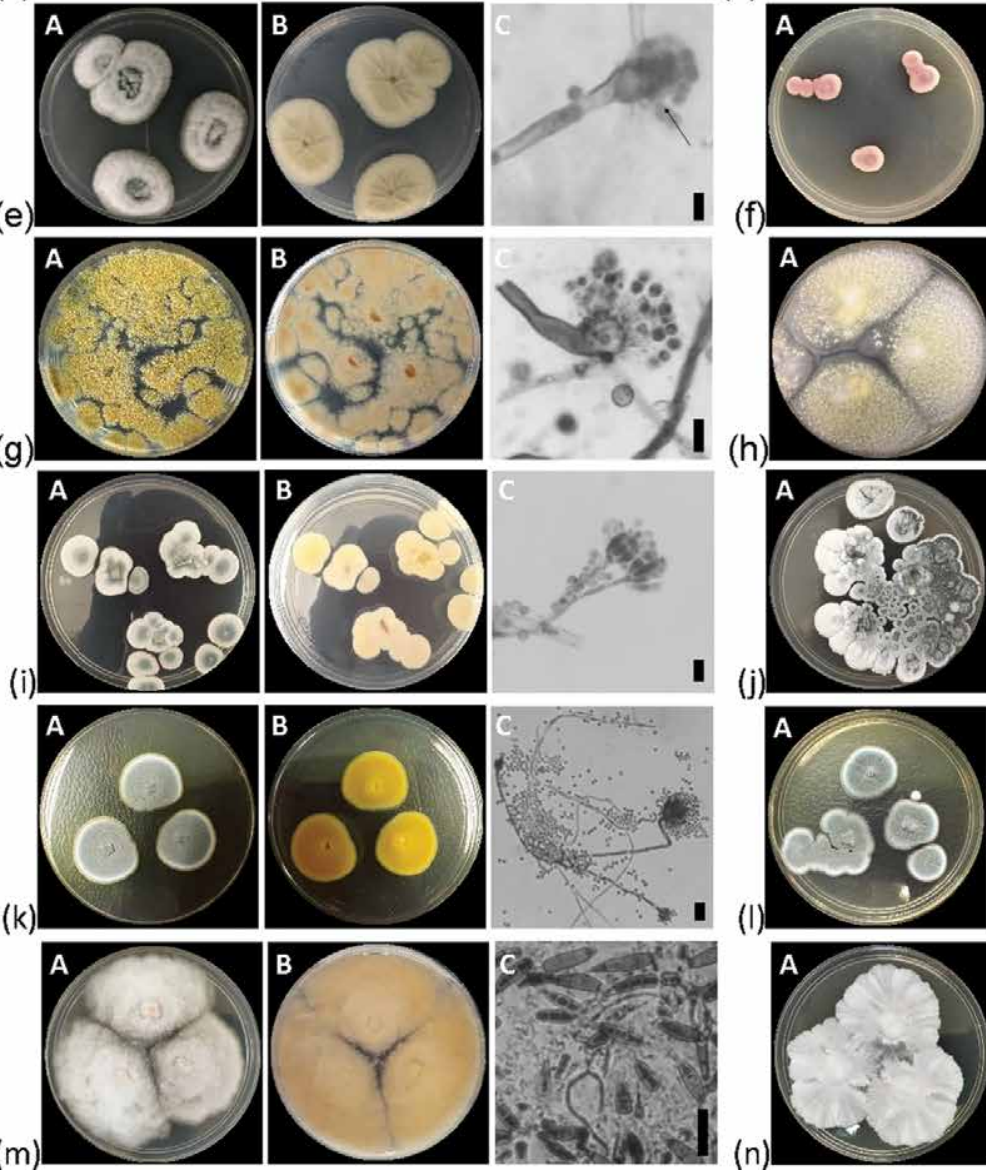
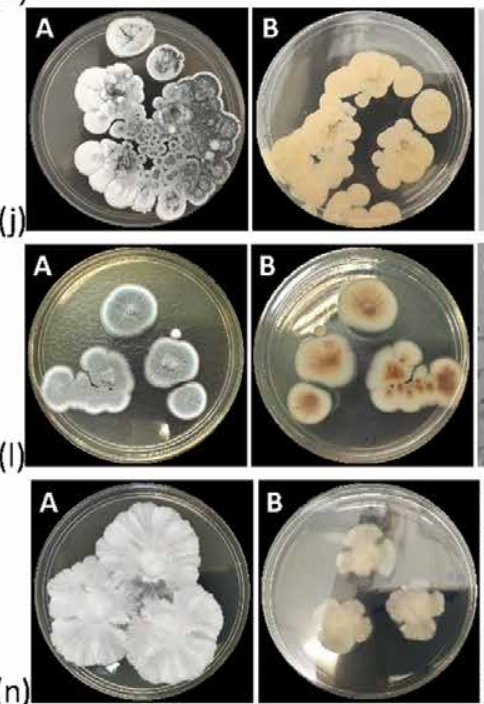
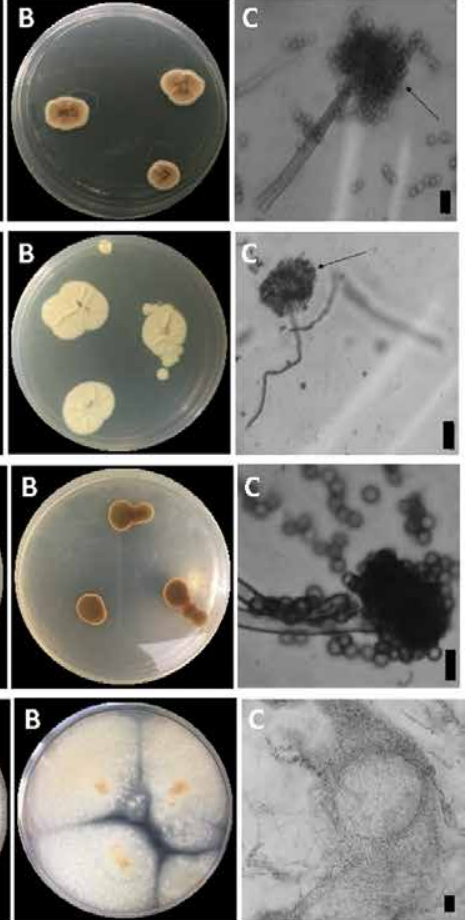

Figure 8. (a) Aspergillus restrictus GMC01; (b) GMC02; (c) GMC03; (d) GMC06; (e) GMC07; (f) GMC11; (g) Aspergillus flavus GMc13; (h) Aspergillus ochraceus GMC12; (i) Penicillium citrinum GMC09; (j) GMC14; (k) Penicillium paxilli GMC04; (I) GMC05; (m) Pestalotiopsis sp. GMC10; (n) Xylaria feejeensis GMC08. A. Colony surface on PDA. B. Colony reverse on PDA. C. Micromorphological characteristics (i.e. conidia, conidiophores, hyphae). Scale $=10 \mu \mathrm{m}$.

spective substrates. They also found that around $3.6-12.0 \%$ of the total OTUs in each respective cave were exclusive to that cave only, although most of these OTUs were unidentified to the genus level. Thus, fungal studies utilizing culture-based methods are still primary and will remain necessary as long as they are required to describe new strains and species, in addition to being cost-effective and more readily available.

Bats can travel faster and traverse larger distances than arthropods, which may account for the higher number of fungal isolates as seen in this study. In this study, six out of the nine fungal species isolated from bats ( $71.4 \%$ of isolates) were isolated from the two frugivorous bat hosts compared to the two insectivorous ones. Although our sample size is not large enough to statistically conclude which group of bats are more efficient as fungal carriers and dispersers, our current data shows that frugivorous bats carried a higher fungal load than insectivorous bats. In a previous study in Sarawak-Borneo, 17 Aspergillus spp. from six species of bats, namely Aspergillus restrictus, $A$. sydowii, A. niger, A. clavatus, and A. japonicus were recorded (Seelan et al., 2008). They reported that the anus and ear yielded the largest number of fungal isolates and showed high fungal diversity. It was noted that various substrate types in wild animal populations resulted in various types of mycoflora, and that the mycoflora found on bats are highly correlated to the food consumed (higher in fruit-eating bats than insect-eating bats) and their roosting site (Seelan et al., 2008). Although fungi and fungal spores exist throughout the cave environment, bats are likely key regulators for the mycoflora of caves, as they are the key transporters in and out of the caves and contribute to guano and carcass deposition (Vanderwolf et al., 2013a, 2013b).

Most studies on bat mycoflora have focused on bat fur (Larcher et al., 2003; Beguin et al., 2005) and P. destructans related surveys (Blehert et al., 2008; Gargas et al., 2009; Puechmaille et al., 2011; Johnson et al., 2013; Zukal et al., 2014). Although there have been bat cadavers sampled for fungal isolation in these studies, none have specifically 
studied fungal diversity exclusively on cadavers until Nováková et al. (2018). Prior to our study, 67 species of fungi have been reported from bat cadavers found in caves throughout the world, with Crysosporium merdarium bring the most frequently isolated (Nováková et al., 2018). Only five other studies had reported fungi from bat cadavers in caves (Zeller, 1996; Wibbelt et al., 2010; Voyron et al., 2011; Vanderwolf et al., 2013b, 2016a, Nováková, 2018). None of the eight fungal species identified from bat cadavers in our study were reported in prior studies on cadavers in caves, and thus are reported for the first time here. None of them were in the genus Chrysosporium, although this is not surprising as fungi from this genus were previously isolated from long-dead decomposed bats.

The bat cadavers in our study were in the early stages of decomposition and were still identifiable morphologically in situ. Nováková et al. (2018) sampled cadavers from both early and late stages of decomposition, even carcasses of only fur and bone, which may have also contributed to the difference in mycobiome from bat cadavers in both studies. Because fungal growth rates are faster on dead bats than live bats, the increased number of bat cadavers in a cave will likely affect fungal diversity found on live bats in the same cave especially after a mass-mortality event (Vanderwolf et al., 2016a).

Along with bats, studies on the insect diversity of Gomantong cave remain scant, with no published reports on arthropod-associated fungi or entomopathogenic fungi in Gomantong cave. The presence of fungi is expected on cave arthropods because many fungi are entomophilous, entomogenous, or entomopathogenic (Ogórek et al., 2013). The arthropods collected in our study were not commonly sampled in previous cave studies, and all three different species of arthropods yielded culturable fungi. Various cave butterflies, crickets, diplopods, harvestmen, moths, mites, and spiders have been previously cultured for fungi, none of which were sampled in our study (Kubátová and Dvorák, 2005, Vanderwolf et al., 2016b; Nováková et al, 2018). The genera Aspergillus and Fusarium tied for having the highest number of isolates for arthropod hosts $(\mathrm{n}=3)$. But all three Fusarium isolates were identified as $F$. solani, whereas the three Aspergillus isolates were identified as the three different species, i.e. A. flavus, A. luteovirescens, and A. sclerotiorum. Penicillium was the only other genus isolated multiple times $(\mathrm{n}=2)$. Aspergillus, Fusarium, and Penicillium are known to have entomogenous species recorded from previous surveys, and it is not surprising to find these taxa in our study (Jurado et al., 2008; Bastian et al., 2010; Vanderwolf et al., 2016b). Whenever Aspergillus, Fusarium, and Penicillium fungi are isolated from cave environmental samples, arthropods should always be considered as major vectors, dispersers, and hosts. One of the most frequent entomopathogenic fungi to be identified in prior cave studies, Isaria furinosa, was not isolated from any arthropod cadavers in this study (Kubátová and Dvorák, 2005). A reduction in the arthropod population in caves, naturally or artificially, could be a way to reduce fungal abundance in the cave or control fungal contamination to other areas within a cave system.

The different species of fungi documented on different arthropod cadavers may be due to differences in movement patterns, feeding location, diet, aggregation and interaction with other individuals, and other external factors. Insects are known to feed on fungi (Šustr et al., 2005; Jacobs et al., 2017). Guano, which is a known substrate of cave fungi, are also feeding grounds for mites that eat guano inhabiting bacteria and fungi (Smrž et al., 2015). Similar arthropods in Gomantong cave, where most of the cave floor is covered in heaps of guano, could be dispersing fungal spores throughout the cave unintentionally. Cockroaches are well known omnivorous scavengers and are likely feeders on sundry organic matter in guano heaps. These same cockroaches would be unintentionally inoculating fungi on bat guano within the cave, as well as dispersing fungal spores already proliferating on the guano to other areas of the cave that can act as substrates, i.e. dead wood (Marcot, 2017), sediment (Taylor et al., 2014), and cave walls (Bastian et al., 2009).

All 14 taxa of fungi isolated from this study have saprophytic properties. Eight of them have been isolated from cave environments prior to this study (Vanderwolf et al., 2013a). A. luteovirescens, A. ochraceus, Diaporthe sp., P. sclerotiorum, $P$. shearii, and Xylaria feejeensis, have not been isolated from the cave environment prior to this study. Ceratobasidium sp. and Diaporthe sp. were not able to be identified at the species level based solely on their ITS barcode. It is unlikely to get a good representation of the overall mycobiome of any cave by evaluating a limited type of substrate or host, i.e. only sampling cadavers. Microbial distribution in caves is heavily determined by the susceptibility of the host, bio-receptivity of the substrate, and environmental conditions (Cuezva et al., 2009; Jurado et al., 2010).

Aspergillus and Penicillium accounted for the highest proportion of fungal diversity in this study, constituting five and four different species out of a total of 14, respectively. They also constituted 17 of the 24 total isolates (70.8\%). Aspergillus restrictus was isolated six times (25\%) from three different species of bats. Aspergillus flavus was the only species isolated from a bat and an arthropod cadaver, C. brachyotis and P. Americana, respectively. Aspergillus spp. are commonly known saprophytes from soil and plant debris (Domsch et al., 2007). Aspergillus and Penicillium are the first and second most reported genera in cave mycological studies aside from the genera Geomyces and Histoplasma, which have a high occurrence due to the many studies focusing specifically on WNS and histoplasmosis, respectively (Vanderwolf et al, 2013a), which is consistent with the finding that Aspergillus spp. and Penicillium spp. are some of the most frequently-isolated fungi from cave soil, rocks, and bat guano (Lorch et al., 2012; Man et al., 2015). Aspergillus spp. and Penicillium spp. were some of the most commonly isolated fungi recovered from bat wings, fur, and skin in North American caves (Johnson et al., 2013; Vanderwolf et al., 2013b). In fact, a variety of Aspergillus and Penicillium 
species have been isolated from dead bats and arthropods in caves as well (Voyron et al., 2011; Nováková, 2018). The fungi identified from cadavers in this study are likely to be found growing on other environmental substrates within the cave, making it easy for the fungi to utilize the cadavers as a carbon source as soon as death occurs.

Fusarium solani (12.5\%), Ceratobasidium sp. (4.2\%), and Diaporthe sp. (4.2\%), were isolated from arthropod cadavers and Pestalotiopsis sp. (4.2\%) and Xylaria feejeensis (4.2\%) were isolated from bat cadavers in this study. These taxa of fungi are known plant pathogens and plant endophytes, which suggests a strong influence of the surrounding plant diversity on the fungal communities in Gomantong cave. Ceratobsidium sp. is the only basidiomycete of all the isolates in this study. Basidiomycetes are less common in the cave environment, but they are the second most frequent division to be isolated (Vanderwolf et al., 2013a). All of these isolates have been reported in the cave environment prior to this study, except Diaporthe sp. and $X$. feejeensis, and thus, they are reported for the first time here (Vanderwolf et al., 2013a). Xylaria spp. are fast-growing fungi usually found in healthy plant tissue (Petrini and Petrini, 1985; Davis et al., 2003), and fungi from this genus have been isolated in the cave from guano, soil, and wood prior to this study (Vanderwolf et al., 2013a). Fusarium solani was the second most isolated taxa in this study, which is congruent with prior findings because this species has been widely reported in caves and is considered a natural part of the cave ecosystem (Bastian et al., 2009). Pestalotiopsis sp. has garnered increased attention in recent years because they produce many important secondary metabolites (Strobel et al., 1996, 2002; Aly et al., 2010; Xu et al., 2010; Maharachchikumbra et al., 2011).

Since these fungi are plant pathogens and endophytes, it may seem unlikely that these fungi would be isolated from bat and arthropods cadavers. However, it is conceivable that the bats and arthropods interacted with these fungi or their spores while traversing the cave or the surrounding forest environment. Bats exit the cave on a regular basis due to their feeding habits and likely interact with Pestalotiopsis sp. and $X$. feejeensis while foraging food in the forest. The arthropods could have picked up Ceratobasidium sp., Diaporthe sp., and $F$. solani mycelia or spores while feeding on decaying organic material, either near the cave entrance or the rear cave floor where plant life is abundant. Cave invertebrates also tend to reside in heaps of guano that are known reservoirs for fungi (Šustr et al., 2005; Nieves-Rivera et al., 2009; Nováková, 2009). Another possibility is that the fungi colonized the cadavers after death, which could happen due to spore dispersal by environmental means, other motile fauna, or human influence.

The geological features of Semud Hitam may have a direct effect on its mycota. The cave has a large cave opening that is about $80 \mathrm{~m}$ high and about $30 \mathrm{~m}$ wide (Lundberg and McFarlane, 2012). Also, in the back end of Semud Hitam, there is a large opening in the ceiling. The sunlight allows for there to be grassy patches exclusively in this part of the cave area (B, Fig, 1; ceiling hole A, Fig. 3). The presence of autotrophs on the cave floor itself is expected to affect the overall fungal diversity of Gomantong cave, and greater fungal diversity is expected near both the cave entrance and back opening (Shapiro and Pringle, 2010; Kuzmina et al., 2012; Mulec et al., 2012). These openings expose a good portion of the cave to precipitation and sunlight and serves as another point of entry for ambient spores, water, organic content, and airflow. Recent studies have suggested that the fungal communities outside the cave play a major role on the fungal diversity within the cave (Zhang and Cai, 2019). Another source of water, organic matter, and spores stems from rainwater being vertically filtered through the soil and rock above the cave (Ikner et al., 2007). During both visits, temperature and relative humidity data did not vary by much (Table 1). But, there was a discernible decrease in temperature and increase in humidity going from the lighted zones to the dark zones. Air temperature and humidity play a significant role in the microbial diversity in the environment (Ogórek et al., 2013). The dark zone of the cave had the lowest temperatures and relative humidity of $100 \%$ during both visits. Gomantong cave showed high relative humidity similar to caves in temperate regions (Nováková et al., 2018).

Gomantong cave, especially Semud Hitam, is a popular ecotourism destination for foreigners and locals. Human visitation may affect cave fungal diversity in a number of ways. There is significant evidence showing that increased human traffic into a cave system will cause contamination of indigenous fungal species by non-indigenous microorganisms (Porca et al., 2011; Griffin et al., 2014). Humans are also responsible for introducing nutrients into a cave (Ikner et al., 2007; Chelius et al., 2009, Shapiro and Pringle, 2010; Pusz et al., 2015). Previous reports have correlated human visitation to lower levels of fungal diversity, but interestingly caves with no human visitations show extremely low fungal abundance (Shapiro and Pringle, 2010). Vandalism in Gomantong cave can be seen on cave walls (Fig. 2A), and previous studies have shown that it affects microbial diversity, although localized to those specific areas (Shapiro and Pringle, 2010). We cannot say how human visitation has changed the mycobiome of Gomantong cave prior to human visitation as the cave has been utilized for swiftlet nest farming for multiple generations. Nonetheless, the increased levels of ecotourism in recent decades have likely affected the microbial diversity in the cave either through spore translocations or nutrient introductions, especially along the boardwalk. All of the samples in this study were collected near or on the boardwalk itself. Comparing the mycobiome of caves with high visitation versus those of low visitation in Sabah has never been done before, and future studies of this nature are highly recommended to better understand tropical cave ecosystems. 
Aspergillus flavus and F. solani are known opportunistic human pathogens. Although Diaporthe sp. was not identified to the species level, it is known that Diaporthe phoenicicola causes scleral keratitis in humans (Gajjar et al., 2011). Recent visitors of caves should always be aware of opportunistic fungal pathogens on the rare chance that they present medical symptoms. More surveys need to be conducted to truly evaluate the potential of emerging infectious diseases of fauna residing in the tropical caves of Borneo.

Currently, we are unaware of any deleterious fungal diseases that affect bats and insects in Sabah's limestone caves. No P. destructans or Geomyces spp. were isolated in this study, likely due to the warmer tropical climate. As the keystone species in many ecosystems, particularly their roles as plant pollinators and insect population control (Mickleburg, et al., 2002; Kunz and Fenton, 2003; Lobova et al., 2009), it is pivotal to monitor the general health of bat populations and to identify any risks that pose a threat to their general wellness. A decline in the population of bats may lead to a cascade of ecological changes that could pose a significant loss to diversity of Bornean bats. Additionally, no obligate entomopathogenic fungi were isolated in this study, but the limited number of sampling days and limited access to all areas of the cave may have played a significant factor. We expect that with more extensive sampling in the future similar entomopathogenic strains that exist in the tropical forests of Borneo would overlap into their caves as well.

Living bats and arthropods are not a food source for most fungi, but their cadavers can be reservoirs for both live fungi and fungal spores. Environmental factors, anthropogenic disturbance, and the natural movement of cave fauna will disperse fungi proliferating on these cadavers into the surrounding environment. Dispersed fungi and their spores will find other suitable substrates to thrive on in the cave, perpetuating further growth. Some saprobic fungi, including ones isolated in this study, can act as opportunistic pathogens to cave fauna and humans (Bastian et al., 2009; Voyron et al., 2011). However, considering their low pathogenic potential to bats and insects, it is likely that the fungi did not play a role in the death of these animals. It is plausible that these animals came in contact with the spores or hyphae from the surface, while traversing the cave environment, or the saprophytic fungi colonized the host cadavers after their deaths. This work corroborates the idea that arthropods and bats contribute to the translocation of fungal spores in and out of the cave and dispersion within the cave itself. There was no evidence of any fungus that required cadavers as their obligatory substrate.

\section{CONCLUSIONS}

Our study is the first to report on the mycobiome of a cave in Borneo and serves as a baseline study to propel future interest and develop skills of researchers. Cave fauna, specifically bats and insects, harbor a multitude of fungi on or in their bodies that represent the mycobiome profile of the surrounding environment. The 14 species of fungi reported from 24 isolates in this study very likely account for an extremely small percentage of the total assemblage of fungi residing within Gomantong caves due to the multitude of potential substrates suitable for fungal growth. None of the fungi isolated are obligate cave dwellers since all taxa have been reported from outside the cave environment. Ongoing studies cultivating fungi from various environmental samples from Gomantong cave is currently in progress. We urge that more studies on cave fungi in Borneo be conducted for their enormous biological and industrial potential, and that future studies use both culture-dependent and culture-independent methods.

\section{ACKNOWLEDGEMENTS}

The authors acknowledge support from Ministry of Education Malaysia (MOE) and Universiti Malaysia Sabah (UMS) who supported this study under the grants FRGS/1/2017/WAB13/UMS/02/2 and Graduate Research Fellowship to IGW GUG0143-1/2017, respectively. We are also grateful to Sabah Forestry Department (Permit No.: JPHTN/TKKH(PSH)100-14/18/2JILID36(47)) and Sabah Wildlife Department for providing access to the sampling site. We also thank the Institute of Tropical Biology and Conservation, Universiti Malaysia Sabah for providing transportation and facilities. We also thank the two anonymous reviewers for improving the manuscript.

\section{REFERENCES}

Abdullah, M.T., Hall, L.S., Tissen, O.B., Tuuga, A., and Cranbrook, S., 2007, The large bat caves of Malaysian Borneo: Bat Research News, v. 48, p. $99-100$.

Aho, R., 1983, Saprophytic fungi isolated from the hair of domestic and laboratory animals with suspected dermatophytosis: Mycopathologia, v. 83, p. 65-73. https://doi.org/10.1007/BF00436886

Ainsworth, G.C., and Austwick, P.K.C., 1955, A survey of animal mycoses in Britain: mycological aspects: Transactions of the British Mycological Society, v. 38, p. 369-386. https://doi.org/10.1016/S0007-1536(55)80040-X

Ali-Shtayeh, M.S., Arda, H.M., Hassouna, M., and Shaheen, S.F., 1988, Keratinophilic fungi on the hair of cows, donkeys, rabbits, cats, and dogs from the West Bank of Jordan: Mycopathologia, v. 104, p. 109-121.

Aly, A.H., Debbab, A., Kjer, J., and Proksch, P., 2010, Fungal endophytes from higher plants: a prolific source of phytochemicals and other bioactive natural products: Fungal Diversity, v. 41, p. 1-16. https://doi.org/10.1007/s13225-010-0034-4

Arouja, J.P.M., and Hughes, D.P., 2016, Diversity of entomopathogenic fungi: Which groups conquered the insects body?: Advances in Genetics, v. 94, p. 1-39. https://doi.org/10.1016/bs.adgen.2016.01.001

Bagy, M.M.K., 1986, Fungi on the hair of large mammals in Egypt: Mycopathologia, v. 93, p. 73-75. https://doi.org/10.1007/BF00437737 
Barton, H.A., Taylor, M.R., and Pace, N.R., 2004, Molecular phylogenetic analysis of a bacterial community in an oligotrophic cave environment: Geomicrobiology Journal, v. 21, p. 11-20. https://doi.org/10.1080/01490450490253428

Bastian, F., Alabouvette, C., and Saiz $\square$ Jimenez, C., 2009, The impact of arthropods on fungal community structure in Lascaux Cave: Journal of Applied Microbiology, v. 106, p. 1456-1462. https://doi.org/10.1111/j.1365-2672.2008.04121.x

Bastian, F., Jurado, V., Nováková, A., Alabouvette, C., and Saiz-Jimenez, C., 2010, The microbiology of Lascaux cave: Microbiology, v. 156, p. 644-652. https://doi.org/10.1099/mic.0.036160-0

Beguin, H., Larcher, G., Nolard, N., and Chabasse, D., 2005, Chrysosporium chiropterorum sp. nov., isolated in France, resembling Chrysosporium state of Ajellomyces capsulatus (Histoplasma capsulatum): Medical Mycology, v. 43, p. 161-169. https://doi. org/10.1080/13693780400006096

Bergman, A., and Casadevall, A., 2010, Mammalian endothermy optimally restricts fungi and metabolic costs: MBio, v. 1, e00212-10. https://doi. org/10.1128/mBio.00212-10

Bills, G.F., 1995, Analyses of microfungal diversity from a user's perspective: Canadian Journal of Botany, v. 73, p. 33-41. https://doi.org/10.1139/ b95-222

Blehert, D.S., Hicks, A.C., Behr, M., Meteyer, C.U., Berlowski-Zier, B.M., Buckles, E.L., Coleman, J.T.H., Darling, S.R., Gargas, A., Niver, R., Okoniewski, J.C., Rudd, R.J., and Stone, W.B., 2009, Bat white-nose syndrome: an emerging fungal pathogen?: Science, v. 323 , p. 227. https://doi.org/10.1126/science.1163874

Boonratana, R. and Sharma, D.S., 1997, Checklist of wildlife species recorded in the Lower Kinabatangan, Sabah: Journal of Wildlife Management and Research Sabah, v. 1, p. 47-60.

Chelius, M.K., Beresford, G., Horton, H., Quirk, M., Selby, G., Simpson, R.T., and Moore, J.C., 2009, Impacts of alterations of organic inputs on the bacterial community within the sediments of Wind Cave, South Dakota, USA: International Journal of Speleology, v. 38, no.1. https://doi. org/10.5038/1827-806X.38.1.1Chinery, M., 2005. Collins Complete Guide to British Insects. HarperCollins.

Collado, J., Platas, G., Paulus, B., and Bills, G. F., 2007, High-throughput culturing of fungi from plant litter by a dilution-to-extinction technique: FEMS Microbiology Ecology, v. 60, p. 521-533. https://doi.org/10.1111/j.1574-6941.2007.00294.x

Cuezva, S., Sanchez-Moral, S., Saiz-Jimenez, S., and Cañaveras, J.C., 2009, Microbial communities and associated mineral fabrics in Altamira Cave, Spain: International Journal of Speleology, v. 38, p. 83-92. https://doi.org/10.5038/1827-806X.38.1.9

Davis, E.C., Franklin, J.B., Shaw, A.J., and Vilgalys, R., 2003, Endophytic Xylaria (Xylariaceae) among liverworts and angiosperms: phylogenetics, distribution, and symbiosis: American Journal of Botany, v. 90, p. 1661-1667. https://doi.org/10.3732/ajb.90.11.1661

Domsch, K.H., Gams, W., and Anderson, T.H., 2007, Compendium of Soil Fungi: Eching, Germany, 672 p. https://doi.org/10.1111/j.13652389.2008.01052_1.x

Gajjar, D.U., Pal, A.K., Parmar, T.J., Arora, A.I., Ganatra, D.A., Ghodadra, B.K., and Vasavada, A. R., 2011, Fungal scleral keratitis caused by Phomopsis phoenicicol:. Journal of Clinical Microbiology, v. 49, p. 2365-2368. https://doi.org/10.1128/JCM.02449-10

Garcia-Solache, M.A., and Casadevall, A., 2010, Global warming will bring new fungal diseases for mammals: mBio, v. 1, p. 1-3. https://doi. org/10.1128/mBio.00061-10

Gargas, A., Trest, M. T., Christensen, M., Volk, T. J., and Blehert, D. S., 2009, Geomyces destructans sp. nov. associated with bat white-nose syndrome: Mycotaxon, v. 108, p. 147-154. https://doi.org/10.5248/108.147

Griffin, D. W., Gray, M. A., Lyles, M. B., and Northup, D. E., 2014, The transport of nonindigenous microorganisms into caves by human visitation: A case study at Carlsbad Caverns National Park: Geomicrobiology Journal, v. 31, p. 175-185. https://doi.org/10.1080/01490451.2013.815294

Gunde-Cimerman, N., Zalar, P., and Jeram, S., 1998, Mycoflora of cave cricket Troglophilus neglectus cadavers. Mycopathologia, v. 141, p. 111-114. https://doi.org/10.1023/A:1006947524503

Hawksworth, D.L., and Lücking, R., 2017, Fungal diversity revisited: 2.2 to 3.8 million species: Microbiology Spectrum, v. 5, p. 1-17. https://doi. org/10.1128/microbiolspec.FUNK-0052-2016

Hibbett, D.S., Ohman, A., and Kirk, P.M., 2009, Fungal ecology catches fire: New Phytologist: v. 184, p. 279-282. https://doi.org/10.1111/j.14698137.2009.03042.x

Higginbotham, S., Wong, W.R., Linington, R.G., Spadafora, C., Iturrado, L., and Arnold, A.E., 2014, Sloth hair as a novel source of fungi with potent anti-parasitic, anti-cancer and anti-bacterial bioactivity: PloS One, v. 9, p. 1-10. https://doi.org/10.1371/annotation/10c47668-8c49-48d2-ba65-60420af463b6

Hobbs, J.J., 2004, Problems in the harvest of edible birds' nests in Sarawak and Sabah, Malaysian Borneo: Biodiversity \& Conservation, v. 13, p. 2209-2226. https://doi.org/10.1023/B:BIOC.0000047905.79709.7f

Ikner, L. A., Toomey, R. S., Nolan, G., Neilson, J. W., Pryor, B. M., and Maier, R. M., 2007, Culturable microbial diversity and the impact of tourism in Kartchner Caverns, Arizona: Microbial Ecology, v. 53, p. 30-42. https://doi.org/10.1007/s00248-006-9135-8

Imes, R., 1992, Practical Entomologist: Simon and Schuster.

Ismail, M.Y., 1999, Social control and bird's nest harvesting among the Idahan: Japanese Journal of Southeast Asian Studies, v. 37, p. 3-17.

Jacobs, A., Msimang, D., and Venter, E., 2017, First survey of the fungi from Bakwena Cave in South Africa suggests low human disturbance: Journal of Cave and Karst Studies, v. 79, p. 89-94. https://doi.org/10.4311/2016MB0146

Johnson, L.J., Miller, A.N., Mccleery, R.A., Mcclanahan, R., Kath, J.A., Lueschow, S., and Porras-Alfaro, A., 2013, Psychrophilic and psychrotolerant fungi on bats and the presence of Geomyces spp. on bat wings prior to the arrival of white nose syndrome: Applied and Environmental Microbiology, v. 79, p. 5465-5471. https://doi.org/10.1128/AEM.01429-13

Jurado, V., Laiz, L., Rodriguez-Nava, V., Boiron, P., Hermosin, B., Sanchez-Moral, S., and Saiz-Jimenez, C., 2010, Pathogenic and opportunistic microorganisms in caves: International Journal of Speleology, v. 39, p. 15-24. https://doi.org/10.5038/1827-806X.39.1.2

Jurado, V., Sanchez-Moral, S., and Saiz-Jimenez, C., 2008, Entomogenous fungi and the conservation of the cultural heritage: A review: International Biodeterioration \& Biodegradation, v. 62, p. 325-330. https://doi.org/10.1016/j.ibiod.2008.05.002

Klich, M.A., 2002, Identification of common Aspergillus species: Centraalbureau voor schimmelcultures, Utrecht, The Netherlands, 116 p. https:// doi.org/10.1017/S0269915X03243123

Kubátová, A., and Dvorák, L., 2005, Entomopathogenic fungi associated with insect hibernating in underground shelters: Czech Mycology, v. 57, p. 221. https://doi.org/10.33585/cmy.57303

Kunz, T.H, Fenton, M.B., eds., 2003, Bat Ecology: University of Chicago Press, Chicago, Illinois, p. 779.

Kuzmina, L.Y., Galimzianova, N.F., Abdullin, S.R., and Ryabova, A.S., 2012, Microbiota of the Kinderlinskaya cave (South Urals, Russia): Microbiology, v. 81, p. 251-258. https://doi.org/10.1134/S0026261712010109 
Lahaye, R., van der Bank, M., Bogarin, D., Warner, J., Puplin, F., Gigot, G., Maurin, O., Duthoit, S., Barraclough, T.G., and Savolainen, V., 2008, DNA barcoding the floras of biodiversity hotspots: Proceedings of the National Academy of Science, USA, v. 105, no. 8, p. 2923-2928. https:// doi.org/10.1073/pnas.0709936105

Larcher, G., Bouchara, J.P., Pailley, P., Montfort, D., Beguin, H., De Bièvre, C., and Chabasse, D., 2003, Fungal biota associated with bats in Western France: Journal de Mycologie Medicale, v. 13, p. 29-34.

Lobova, T.A., Geiselman, C.K., and Mori, S.A., 2009, Seed dispersal by bats in the Neotropics: Memoirs of the New York Botanical Garden, v. 101, p. 471.

Lorch, J.M., Lindner, D.L., Gargas, A., Muller, L.K., Minnis, A.M., and Blehert, D.S., 2013, A culture-based survey of fungi in soil from bat hibernacula in the eastern United States and its implications for detection of Geomyces destructans, the causal agent of bat white-nose syndrome: Mycologia, v. 105, p. 237-252. https://doi.org/10.3852/12-207

Lundberg, J., and Mcfarlane, D.A., 2012, Post-speleogenetic biogenic modification of Gomantong caves, Sabah, Borneo. Geomorphology, v. 157, p. 153-168. https://doi.org/10.1016/j.geomorph.2011.04.043

Maharachchikumbura, S.S., Guo, L.D., Chukeatirote, E., Bahkali, A.H., and Hyde, K.D., 2011, Pestalotiopsis-morphology, phylogeny, biochemistry and diversity: Fungal Diversity, v. 50, p. 167-187. https://doi.org/10.1007/s13225-011-0125-x

Malloch, D., and Blackwell, M., 1993, Dispersal biology of ophiostomatoid fungi, in Wingfield, M.J., Seifert, K.A., Webber, J.F., eds., Ceratocystis and Ophiostoma. Taxonomy, Ecology and Pathologenicity: Saint Paul, MN, USA, APS Press, p. 195-206.

Man, B., Wang, H., Xiang, X., Wang, R., Yun, Y., and Gong, L., 2015, Phylogenetic diversity of culturable fungi in the Heshang Cave, central China: Frontiers in Microbiology, v. 6, 1158. https://doi.org/10.3389/fmicb.2015.01158

Marcot, B.G., 2017, A review of the role of fungi in wood decay of forest ecosystems: Portland, OR: US Department of Agriculture, Forest Service, Pacific Northwest Research Station, Research Note PNW-RN-575 p. 1-31.

Mickleburgh, S.P., Hutson, A.M., and Racey, P.A., 2002, A review of the global conservation status of bats: Oryx, v. 36, p. 18-34. https://doi. org/10.1017/S0030605302000054

Mulec, J., Vaupoti c, J., and Walochnik, J., 2012, Prokaryotic and eukaryotic airborne micoorganisms as tracers of microclimatic changes in the underground (Postojna Cave, Slovenia): Microbial Ecology, v. 64, p. 654-667. https://doi.org/10.1007/s00248-012-0059-1

Nieves-Rivera, Á.M., Santos-Flores, C.J., Dugan, F.M., and Miller, T.E., 2009, Guanophilic fungi in three caves of southwestern Puerto Rico: International Journal of Speleology, v. 38, p. 61-70. https://doi.org/10.5038/1827-806X.38.1.7

Nováková, A., 2009, Microscopic fungi isolated from the Domica Cave system (Slovak Karst National Park, Slovakia): a review: International Journal of Speleology, v. 38, no. 1, p. 71-82. https://doi.org/10.5038/1827-806X.38.1.8

Nováková, A., Kubátová, A., Sklenár,, F., and Hubka, V., 2018, Microscopic fungi on cadavers and skeletons from cave and mine environments: Czech Mycology, v. 70, p. 101-121. https://doi.org/10.33585/cmy.70201

O'Donnell, K., Sutton, D.A., Fothergill, A., McCarthy, D., Rinaldi, M.G., Brandt, M.E., Zhang, N., and Geiser, D.M., 2008, Molecular phylogenetic diversity, multilocus haplotype nomenclature, and in vitro antifungal resistance within the Fusarium solani species complex: Journal of Clinical Microbiology, v. 46, p. 2477-2490. https://doi.org/10.1128/JCM.02371-07

Ogórek, R., Lejman, A., and Matkowski, K., 2013, Fungi isolated from Niedźwiedzia cave in Kletno (lower Silesia, Poland): International Journal of Speleology, v. 42, p. 161-166. https://doi.org/10.5038/1827-806X.42.2.9

Otero, J.T., Ackerman, J.D., and Bayman, P., 2004, Differences in mycorrhizal preferences between two tropical orchids: Molecular Ecology, v. 13, p. 2393-2404. https://doi.org/10.1111/j.1365-294X.2004.02223.x

Pflitsch, A., and Piasecki, J., 2003, Detection of an airflow system in Niedzwiedzia (Bear) cave, Kletno, Poland: Journal of Cave and Karst Studies, v. 65, p. 160-173.

Petrini, L., and Petrini, O, 1985, Xylariaceous fungi as endophytes. Sydowia, v. 38, p. 216-234.

Polovinko, G.P., Yaroslavtseva, O.N., Teshebaeva, Z.A., and Kryukov, V.Y., 2010, Dominating species of entomophilous ascomycetes anamorphs in West Siberia, Primorsky krai, and Kyrgyzstan: Contemporary Problems of Ecology, v. 3, p. 515-521. https://doi.org/10.1134/ S1995425510050024

Porca, E., Jurado, V., Martin-Sanchez, P.M., Hermosín, B., Bastian, F., Alabouvette, C., and Sáiz-Jiménez, C., 2011, Aerobiology: an ecological indicator for early detection and control of fungal outbreaks in caves: Ecological Indicators, v. 11, p. 1594-1598. https://doi.org/10.1016/j. ecolind.2011.04.003

Poulson T.L., 1972, Bat guano ecosystems: Bulletin of the National Speleological Society, v. 72, p. 55-59.

Puechmaille, S.J., Wibbelt, G., Korn, V., Fuller, H., Forget, F., Mühldorfer, K., Kurth, A., Bogdanowicz, W., Borel, C., Bosch, T., Cherezy, T., Drebet, M., Görföl, T., Haarsma, A., Herhaus, F., Hallart, G., Hammer, M., Jungmann, C., Bris, Y.L., Lutsar, L., Masing, M., Mulkens, B., Passior, K., Starrach, M., Wojtaszewski, A., Zöphel, U., and Teeling, E., 2011, Pan-European distribution of white-nose syndrome fungus (Geomyces destructans) not associated with mass mortality: PloS One, v. 6, e19167. https://doi.org/10.1371/journal.pone.0019167

Pusz, W., Ogórek, R., Knapik, R., Kozak, B., and Bujak, H., 2015, The occurrence of fungi in the recently discovered Jarkowicka cave in the Karkonosze Mts. (Poland): Geomicrobiology Journal, v. 32, p. 59-67. https://doi.org/10.1080/01490451.2014.925010

Raper, K.B., and Fennell, D.I., 1965, The Genus Aspergillus: Baltimore, Williams and Wilkins, 686 p.

Rees, R.G. (1967). Keratinophilic fungi from Queensland-I. Isolations from animal hair and scales: Sabouraudia: Journal of Medical and Veterinary Mycology, v. 5, p. 165-172. https://doi.org/10.1080/00362176785190351

Santamaria, S., and Faille, A., 2007, Rachomyces (Ascomycota, Laboulbeniales) parasites on cave-inhabiting Carabid beetles from the Pyrenees: Nova Hedwigia, v. 85, p. 159-186. https://doi.org/10.1127/0029-5035/2007/0085-0159

Seelan, S.S.J., and Anwarali, F., 2009, Case report of a new pathogenic variant of Aspergillus fumigatus isolated from Hipposideros cervinus (Chiroptera: Hipposideridae) in Sarawak, Malaysia: Journal of Threatened Taxa, v. 1, p. 190-191. https://doi.org/10.11609/JoTT.o2084.190-91

Seelan, S.S.J., Anwarali, F.A., Sepiah, M., and Abdullah, M.T., 2008, Bats (chiropteran) reported with Aspergillus species from Kubah National Park, Sarawak, Malaysia. Journal of Tropical Biology and Conservation, v. 4, p. 81-97.

Shapiro, J., and Pringle, A., 2010, Anthropogenic influences on the diversity of fungi isolated from caves in Kentucky and Tennessee: The American Midland Naturalist, v. 163, p. 76-86. https://doi.org/10.1674/0003-0031-163.1.76

Sidrim, J.J.C., Moreira Filho, R.E., Cordeiro, R.A., Rocha, M.F.G., Caetano, E.P., Monteiro, A.J., and Brilhante, R.S.N., 2010, Fungal microbiota dynamics as a postmortem investigation tool: Focus on Aspergillus, Penicillium and Candida species: Journal of Applied Microbiology, v. 108, p. 1751-1756. https://doi.org/10.1111/j.1365-2672.2009.04573.x

Smrž, J., Kováč, L., Mikeš, J., Šustr, V., Lukešová, A., Tajovsky, K., Nováková, A., and Režňáková, P., 2015, Food sources of selected terrestrial cave arthropods: Subterranean Biology, v. 16, p. 37-46. https://doi.org/10.3897/subtbiol.16.8609 
Strobel, G., Yang, X., Sears, J., Kramer, R., Sidhu, R.S., and Hess, W.M., 1996, Taxol from Pestalotiopsis microspora, an endophytic fungus of Taxus wallachiana: Microbiology, v. 142, p. 435-440. https://doi.org/10.1099/13500872-142-2-435

Strobel, G., Ford, E., Worapong, J., Harper, J.K., Arif, A.M., Grant, D.M., Fung, P.C.W., and Chau, R.M.W., 2002, Isopestacin, an isobenzofuranone from Pestalotiopsis microspora, possessing antifungal and antioxidant activities: Phytochemistry, v. 60, p. 179-183. https://doi. org/10.1016/S0031-9422(02)00062-6

Šustr, V., Elhottová, D., Krištůfek, V., Lukešová, A., Nováková, A., Tajovský, K., and Tríska, J., 2005, Ecophysiology of the cave isopod Mesoniscus graniger (Frivaldszky, 1865) (Crustacea: Isopoda): European Journal of Soil Biology, v. 41, p. 69-75. doi:10.1016/j.ejsobi.2005.09.008. https://doi.org/10.1016/j.ejsobi.2005.09.008

Taylor, E.L.S., Ferreira, R.L., Cardoso, P.G., and Stoianoff, M.A.R., 2014, Cave entrance dependent spore dispersion of filamentous fungi isolated from various sediments of iron ore cave in Brazil: a colloquy on human threats while caving: Ambient Science, v. 1, p.16--28. https://doi. org/10.21276/ambi.2014.01.1.ra02

Tristan, C., Cécile, R., Xavier, C., Desprez-Loustaua, M.L., Corinne, V., 2012, Spatial variability of phyllosphere fungal assemblages: genetic distance predominates over geographic distance in a European beech stand (Fagus sylvatica): Fungal Ecology, v. 5, p. 509-520. https://doi. org/10.1016/j.funeco.2011.12.004

Unterseher, M., and Schnittler, M., 2009, Dilution-to-extinction cultivation of leaf-inhabiting endophytic fungi in beech (Fagus sylvatica L.)-different cultivation techniques influence fungal biodiversity assessment: Mycological Research, v. 113, p. 645-654. https://doi.org/10.1016/j. mycres.2009.02.002

Vanderwolf, K.J., Malloch, D., McAlpine, D.F., and Forbes, G.J., 2013a, A world review of fungi, yeasts and slime molds in caves: International Journal of Speleology, v. 42, no. 1, p. 77-96. https://doi.org/10.5038/1827-806X.42.1.9

Vanderwolf, K.J., McAlpine, D.F., Malloch, D., and Forbes, G.J., 2013b, Ectomycota associated with hibernating bats in eastern Canadian caves prior to the emergence of white-nose syndrome: Northeastern Naturalist, v. 20, p. 115-131. https://doi.org/10.1656/045.020.0109

Vanderwolf, K.J., Malloch, D., and McAlpine, D.F., 2016a, Fungi on white-nose infected bats (Myotis spp.) in Eastern Canada show no decline in diversity associated with Pseudogymnoascus destructans (Ascomycota: Pseudeurotiaceae): International Journal of Speleology, v. 45, p. 43-50. https://doi.org/10.5038/1827-806X.45.1.1946

Vanderwolf, K., Malloch, D., and McAlpine, D., 2016b, Ectomycota associated with arthropods from bat hibernacula in eastern Canada, with particular reference to Pseudogymnoascus destructans: Insects, v. 7, p. 16. https://doi.org/10.3390/insects7020016

Visagie, C.M., Yilmaz, N., Vanderwolf, K., Renaud, J.B., Sumarah, M.W., Houbraken, J., Assebgui, R., Seifert, K.A., and Malloch, D., 2019, Penicillium diversity in Canadian bat caves, including a new species, $P$. speluncae: Fungal Systematics and Evolution, v. 5, p. 1-15. https://doi. org/10.3114/fuse.2020.05.01

Voyron, S., Lazzari, A., Riccucci, M., Calvini, M., and Varese, G., 2011, First mycological investigation on Italian bats: Hystrix, the Italian Journal of Mammalogy, v. 22, p. 189-197.

Wang, W., Ma, X., Ma, Y., Mao, L., Wu, F., Ma, X., and Feng, H., 2010, Seasonal dynamics of airborne fungi in different caves of the Mogao Grottoes, Dunhuang, China: International Biodeterioration \& Biodegradation, v. 64, p. 461-466. https://doi.org/10.1016/j.ibiod.2010.05.005

White, T.J., Burns, T., Lee, S. and Taylor, J., 1990, Amplification and direct sequencing of fungal ribosomal RNA genes for phylogenetics, in Innis, M.A., Gelfand, D.H., Sninsky, J.J., White, T.J., eds., PCR protocols: a guide to methods and applications: San Diego, Academic Press, p. 315-322. https://doi.org/10.1016/B978-0-12-372180-8.50042-1

Wibbelt, G., Kurth, A., Hellmann, D., Weishaar, M., Barlow, A., Veith, M., Prüger, J., Görföl, T., Grosche, L., Bontadina, F., Zöphel, U., Seidl, H., Cryan, P.M., Blehert, D.S., 2010, White-nose syndrome fungus (Geomyces destructans) in bats, Europe: Emerging Infectious Diseases, v. 16, p. 1237. https://doi.org/10.3201/eid1608.100002

Winter, A.S., Hathaway, J.J., Kimble, J.C., Buecher, D.C., Valdez, E.W., Porras-Alfaro, A., Young, J.M, Read, K.J.H., and Northup, D.E., 2017, Skin and fur bacterial diversity and community structure on American southwestern bats: effects of habitat, geography and bat traits: PeerJ, $v$. 5, e3944.

Woese, C.R., Kandler, O., and Wheelis, M.L., 1990, Towards a natural system of organisms: proposal for the domains Archaea, Bacteria, and Eucarya: Proceedings of the National Academy of Science, USA, v. 87, no. 12, p. 4576-4579. https://doi.org/10.1073/pnas.87.12.4576

Xu, J., Ebada, S.S., and Proksch, P., 2010, Pestalotiopsis a highly creative genus: chemistry and bioactivity of secondary metabolites: Fungal Diversity, v. 44, p. 15-31. https://doi.org/10.1007/s13225-010-0055-z

Yoder, J.A., Benoit, J.B., Christensen, B.S., Croxall, T.J., and Hobbs, H.H., 2009, Entomopathogenic fungi carried by the cave orb weaver spider Meta ovalis (Araneae, Tetragnathidae), with implications for mycoflora transfer to cave crickets: Journal of Cave and Karst Studies, v. 71, p. $116-120$.

Zeller, L., 1966, Keratinophilic fungi from the "Baradla" cave in Aggtelek: Annals of the University of Sciences Budapest, Section Biology, v. 8, p. 375-388.

Zhang, Z., Schwartz, S., Wagner, L., and Miller, W., 2000, A greedy algorithm for aligning DNA sequences. Journal of Computational Biology, v. 7, p. 203-214. https://doi.org/10.1089/10665270050081478

Zhang, T., Victor, T.R., Rajkumar, S.S., Li, X., Okoniewski, J.C., Hicks, A.C., Davis, A.D., Broussard, K., LaDeau, S.L., Chaturvedi, S., and Chaturvedi, V., 2014, Mycobiome of the bat white nose syndrome affected caves and mines reveals diversity of fungi and local adaptation by the fungal pathogen Pseudogymnoascus (Geomyces) destructans: PloS One, v. 9, e108714. https://doi.org/10.1371/journal.pone.0108714

Zhang, Z.F., and Cai, L., 2019, Substrate and spatial variables are major determinants of fungal community in karst caves in Southwest China: Journal of Biogeography, v. 46, p. 1504-1518. https://doi.org/10.1111/jbi.13594

Zhang, Z.F., Liu, F., Zhou, X., Liu, X.Z., Liu, S.J., and Cai, L., 2017, Culturable mycobiota from Karst caves in China, with descriptions of 20 new species. Persoonia: Molecular Phylogeny and Evolution of Fungi, v. 39, p. 1-31. https://doi.org/10.3767/persoonia.2017.39.01

Zukal, J., Bandouchova, H., Brichta, J., Cmokova, A., Jaron, K.S., Kolarik, M., Kovacova, V., Kubátová, A., Nováková, A., Orlov, O., Pikula, J., Presetnik, P., Šuba, J., Zahradníková Jr., A., and Martínková, N., 2014, White-nose syndrome fungus: a generalist pathogen of hibernating bats: PLoS One, v. 9, e97224. https://doi.org/10.1371/journal.pone.0097224. 